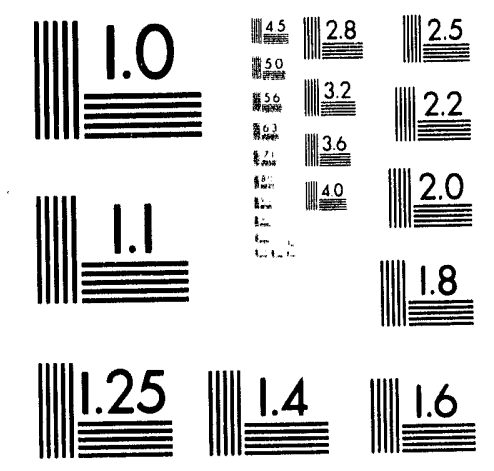



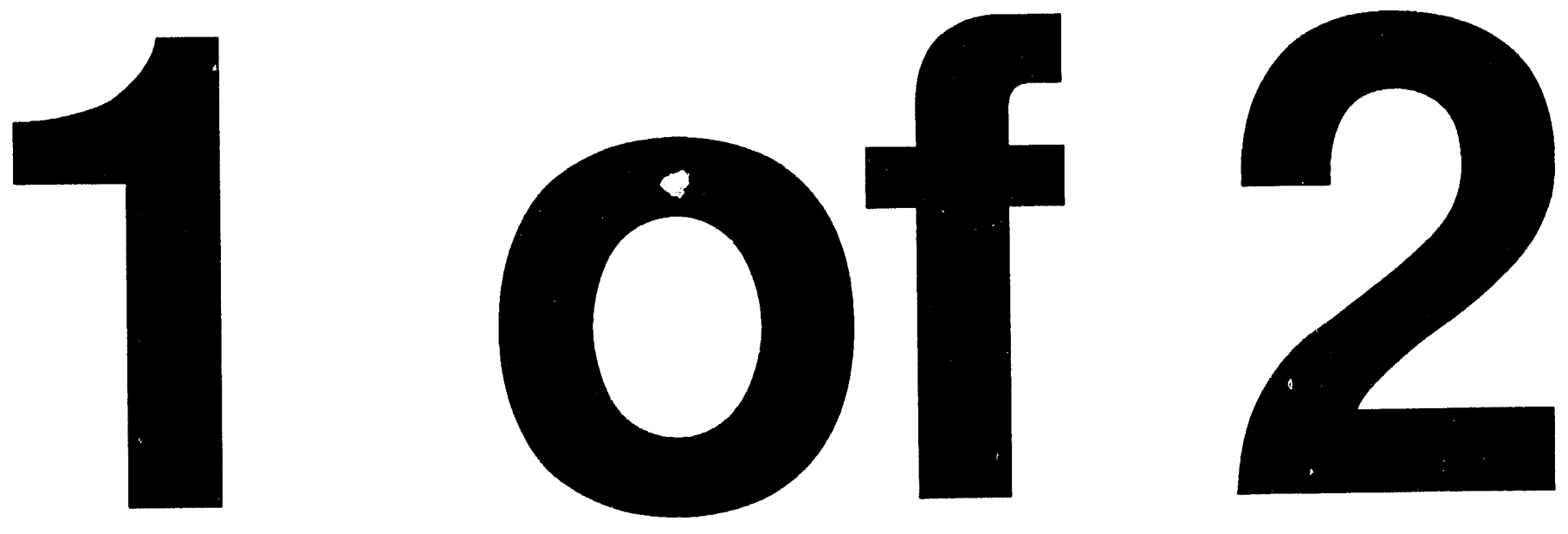
NUREG-0936

Vol. 12, No. 3

\section{NRC Regulatory Agenda}

Quarterly Report

July-September 1993

Manuscript Completed: October 1993

Date Published: October 1993

Division of Freedom of Information and Publications Services

Office of Administration

U.S. Nuclear Regulatory Commission

Washington, DC 20555

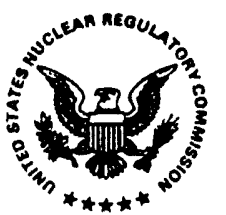


TABLE OF CONTENTS

SECTION I - RULES

(A) Rules on which final action has been taken

since June 30,1993

Page

Procedures Involving the Equal Access to Justice Act:

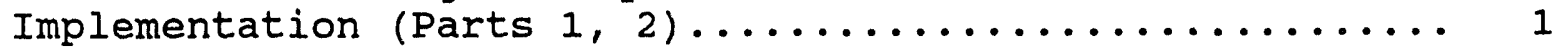

Radioactive Waste Below Regulatory Concern; Generic

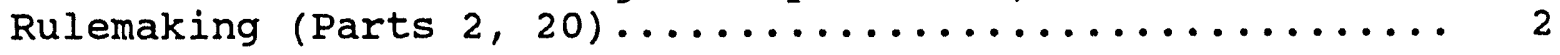

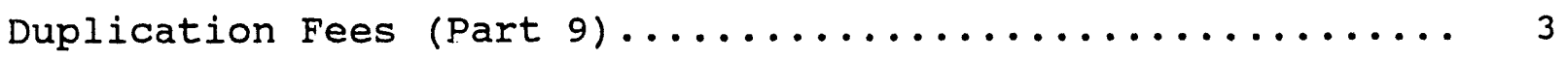

Access Authorization Fee Schedule for Licensee Personnel

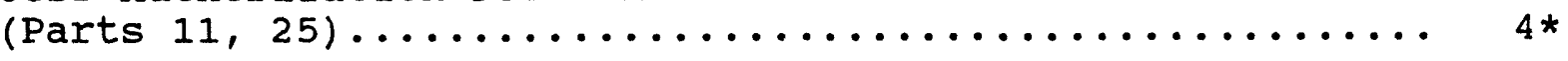

Authorization to Prepare Radiopharmaceutical Reagent

Kits and Elute Radiopharmaceutical Generators; Use of

Radiopharmaceuticals for Therapy; Extension of

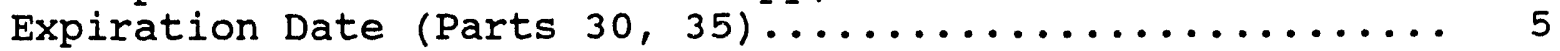

Decommissioning Recordkeeping and License Termination:

Documentation Additions (Parts $30,40,50,70,72$ )...... 6

Certification of Industrial Radiographers (Parts 34, 150)... 7

Iridium-192 wire for Interstitial Treatment of Cancer

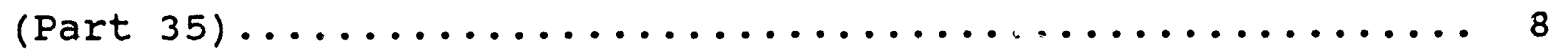

Loss of All Alternating Current Power (Part 50)......... 9

FSAR Update Submittals (Part 54$) \ldots \ldots \ldots \ldots \ldots \ldots$

Day Firing Qualifications for Security Personnel at

Category I Licensee Fuel Cycle Facilities (Part 73) ....... 11

Adjustment of the Maximum Standard Deferred Premium

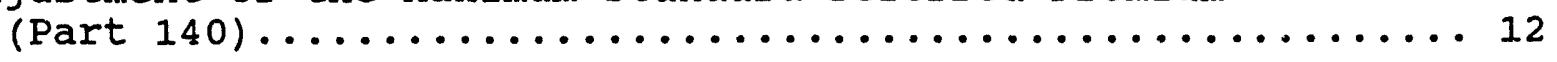

FY 1991 and FY 1992 Final Rule Implementing the U.S. Court of Appeals Decision and Revision of Fee Schedules;

100\% Fee Recovery, FY 1993 (Parts 170, 171)........... 13

Nuclear Regulatory Commission Acquisition Regulation;

Minor Amendments (48 CFR Parts 2017, 2052)............ 14 
(B) Proposed Rules

Availability of official Records (Part 2)............ 15

Interim storage of Spent Fuel in an Independent spent Fuel Storage Installation; Site-Specific License to a Qualified Applicant (Parts 2,72 )................ 17

Equal Access to Justice Act: Implementation (Part 12) .... 18

Whistleblower Protection for Nuclear Power Plant Employees (Parts 19, 30, 40, 50, 60, 61, 70, 72, 150)..........

Low-Level Waste Manifest Information and Reporting

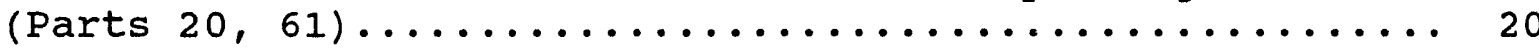

Modifications to Fitness-for-Duty Program Requirements

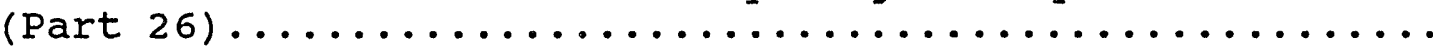

Procedures and Criteria for on-Site Storage of Low-Level Radioactive waste (Parts $30,40,50,70,72$ ).......... 23

Self-Guarantee as an Additional Financial Assurance Mechanism (Parts $30,40,50,70,72$ )............... 24

Timeliness in Decommissioning of Materials Facilities

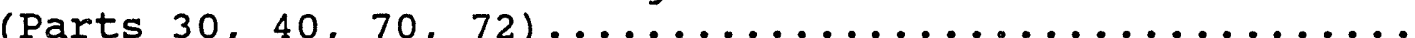

Requirements for Possession of Industrial Devices Containing Byproduct Material (Parts 31, 32)..........

Requirements Concerning the Accessible Air Gap for Generally Licensed Devices (Parts 31, 32)............ 28

Preparation, Transfer for Commercial Distribution, and Use of Byproduct Material for Medical Use (Part 35)..... 29

Licensee Submittal of Data in Computer-Readable Form

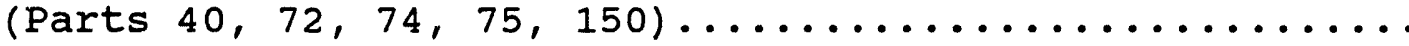

Notification of Spent Fuel Management and Funding Plans by Licensees of Prematurely Shut Down Power Reactors

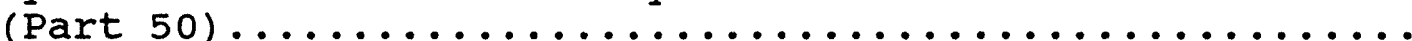

Clarification of Emergency Preparedness Regulations;

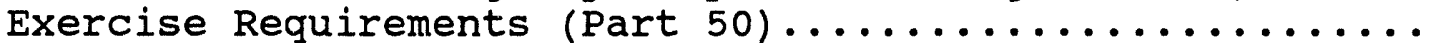

Reactor Site Criteria; Including Seismic and Earthquake Engineering Criteria for Nuclear Power Plants (Parts

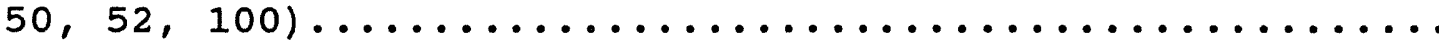


Page

Primary Reactor Containment Leakage Testing for Water-Cooled Power Reactors (Part 50) ............. 34

Addition of Radon-222 and Technetium-99 Values to Table $\mathrm{S}-3$ and Revisions Resulting from Consideration of

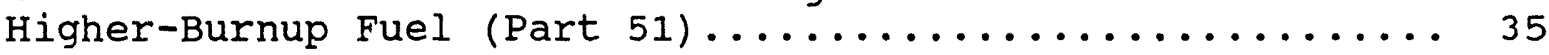

License Renewal for Nuclear Power Plants; Scope of Environmental Effects (Part 51)................ 37

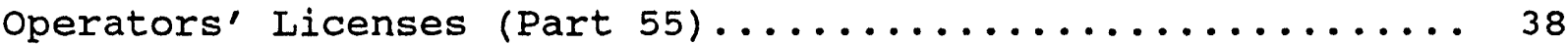

Elimination of Inconsistencies Between NRC Regulations

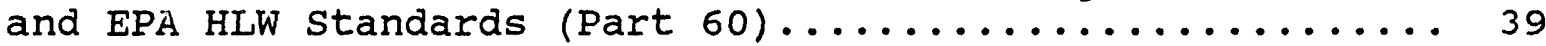

Clarification of Assessment Requirements for Siting Criteria and Performance Objectives (Part 60)......... 40

Update of Transportation Regulations to Incorporate New Licensing Information (Part 71) ................ 41

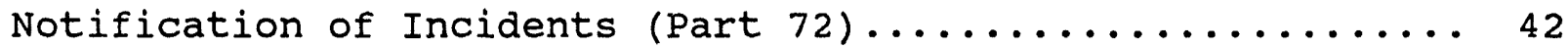

List of Approved Spent Fuel storage Casks: Addition of

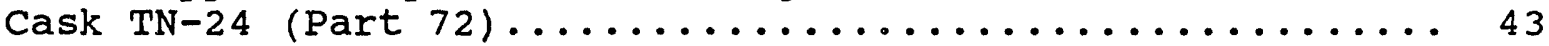

Emergency Planning for Independent Spent Fuel Storage Facilities (ISFSI) and Monitored Retrievable Storage Facilities (MRS) (Part 72) ................... 44

Import and Export of Radioactive Waste (Part 110) .......445

Specific Licensing of Exports of Certain Alpha-Emitting Radionuclides and Byproduct Material (Part 110)........ 46

Criteria for an Extraordinary Nuclear Occurrence (Part 140) ................................ 48

Reasserting NRC's Sole Authority for Approving onsite Low-level Waste Disposal in Agreement States (Part 150)...

Restoration of Generic Exemption from Annual Fees for Nonprofit Educational Institutions (Part 171) ......... 50*

(C) Advance Notices of Proposed Rulemaking

Comprehensive Quality Assurance in Medical Use and a

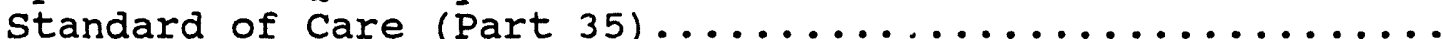


Page

Licensing of Source Material (Part 40) .............. 52

Acceptance of Products Purchased for Use in Nuclear

Power Plant Structures, Systems, and Components

(Part 50)

Acceptability of Plant Performance for Severe Accidents;

Scope of Consideration in Safety Regulations (Part 50) ... 55

NRC Fee Policy (Parts 170, 171)................... 56

(D) Unpublished Rules

Supplemental Standards of Ethical Conduct for Employees

of the Nuclear Regulatory Commission (Part 0 )...........

Revised Rules of Practice for Domestic Licensing

Proceedings (Parts $0,1,2,9,50) \ldots \ldots \ldots \ldots \ldots \ldots \ldots \ldots$

Statement of Organization and General Information;

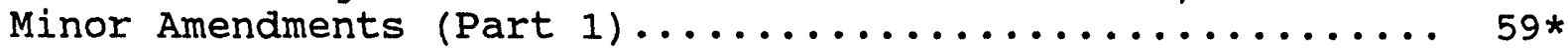

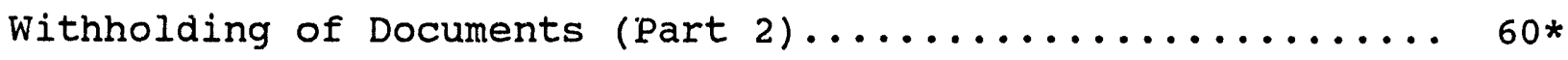

Informal Hearing Procedures for Materials Licensing Adjudications (Part 2) ........................ 61

Discrimination on the Basis of Sex (Parts 2, 19)........ 62

Revision of Specific Exemptions (Part 9) ............. 63

Radiation Protection Requirements; Amended Definitions and Criteria (Parts 19, 20) ..................... $64 *$

Radiological Criteria for Decommissioning of Nuclear

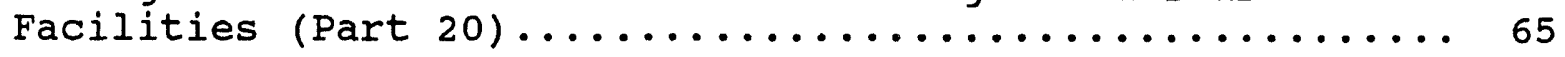

Disposal by Release into Sanitary Sewerage (Part 20) ..... 67*

Release Criteria for Patients Administered Radioactive

Materials (Parts 20,35 )........................ 68

NRC Operations Center; Commercial Telephone Number

Change (Parts 20, 21, 30, 35, 40, 50, 70, 72, 73)...... 69*

Clarification of Reporting of Defects and Noncompliance for Materials Facilities (Part 21).................. 70 
Page

Reporting Requirements for Transfer of Products to Persons Exempt from Licensing Requirements (Fart 32)......... 71

Radiography and Radiation Safety Requirements for Radiography operations (Part 34) ................ 72

Administration of Byproduct Material or Radiation to Patients Who May Be Pregnant or Breast-Feeding (Part 35) . 73

Design and Performance Criteria for Sealed Sources Used in Well Logging (Part 39) ..................... 74

Uranium Tailings Regulations; Conforming NRC Requirements

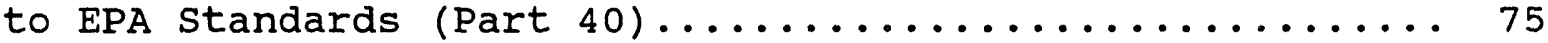

Thermal Annealing of the Reactor Pressure Vessel

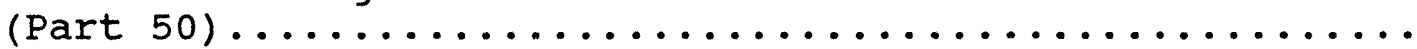

Consideration of the Possible Effects of Power Reactor Ownership Arrangements on Safety (Part 50) .......... 78

Safety Requirements for Reactor Coolant Pump Seals

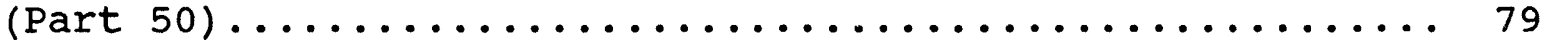

Changes to Quality Assurance Programs (Part 50)......... 80

Definition of Commitment (Part 50$) \ldots \ldots \ldots \ldots \ldots \ldots$

Changes to Fire Protection Plans (Part 50)............ 82

Changes to Emergency Plans (Part 50)............... 83

Changes to security Plans (Part 50 )................. 84

Codes and Standards for Nuclear Power Plants (ASME B\&PV Code, 1989/1990/1991/1992/1993 Addenda and 1992 Edition, Appendix VIII, Safety-Related Snubbers and the ASME OM Code-1990 Edition, 1992 Addenda and 1993 Addenda)

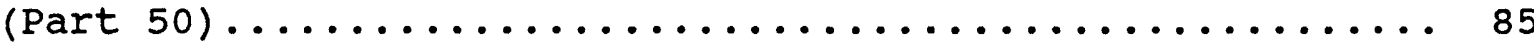

Codes and Standards for Nuclear Power Plants (ASME Code, Section XI, Division 1, Subsection IWE and Subsection

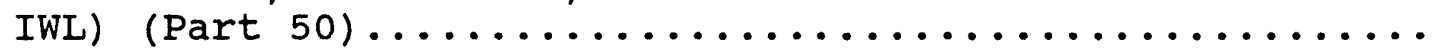

Fracture Toughness Requirements for LWR Pressure Vessels

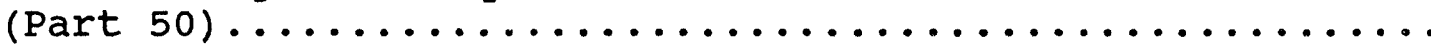

Standardized Plant Designs, Early Review of Site Suitability Issues; Clarifying Amendments (Parts 50,

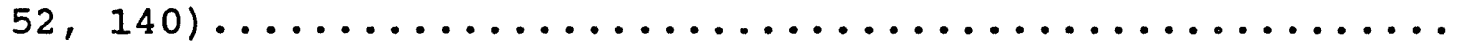


Page

Design Certification for Evolutionary Light water

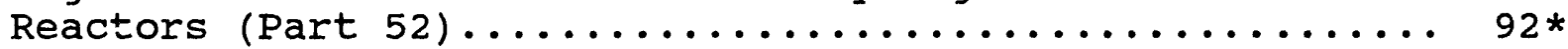

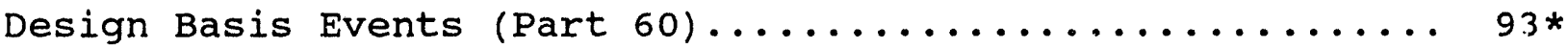

Land Ownership Requirements for Low-Level Waste Sites

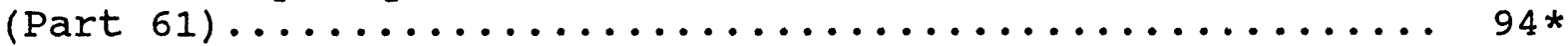

Financial Assurance for Low-Level Waste Disposal Site

Surveillance, Monitoring, and Custodial Care

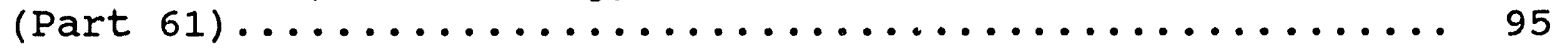

Removal of Criticality Alarm Requirements for Fresh

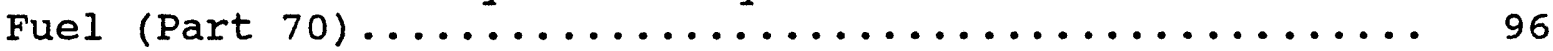

Physical Fitness Programs for Security Personnel at

Category I Licensee Fuel Cycle Facilities (Part 73) ..... 97

Reinvestigation of Individuals Granted Unescorted Access

to Nuclear Power Plants (Part 73)................. 98

Night Firing Qualifications for Security Guards at Nuclear Power Plants (Part 73) .................. 99

Physical Protection of Special Nuclear Material in

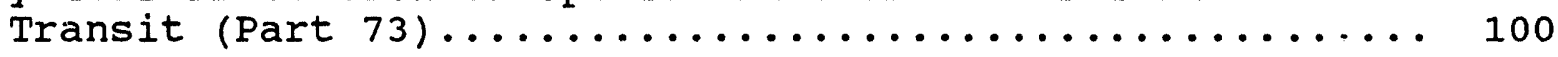

Protection Against Malevolent Use of Vehicles at Nuclear Power Plants (Part 73) ................... 101*

Standards for Certification of DOE Uranium Enrichment Gaseous Diffusion Facilities (Part 76)............. 102

SECTION II - PETITIONS FOR RULEMAKING

(A) Petitions incorporated into final rules or petitions denied since June 30,1993

Amersham Corporation $(\mathrm{PRM}-35-8) \ldots \ldots \ldots \ldots \ldots \ldots$

(B) Petitions incorporated into proposed rules

None 
(C) Petitions pending staff review

Carol S. Marcus, Ph.D., M.D. (PRM-20-20).............. 105

Keith J. Schiager, Ph.D., et al. (PRM-20-21).......... 106*

Advanced Medical systems, Inc. (PRM-32-3) ............ 107

International Union of Operating Engineers, Local No. 2

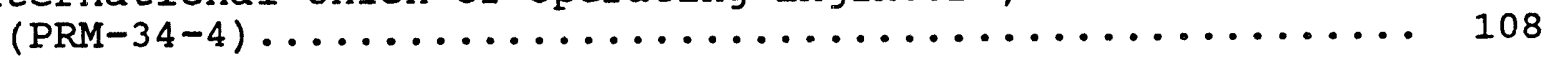

American College of Nuclear Medicine (PRM-35-10/

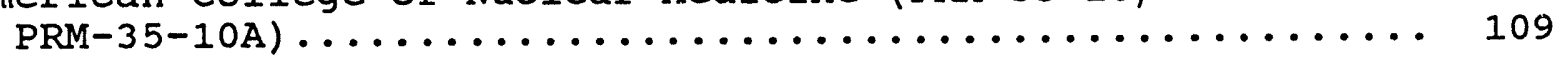

The Ohio Citizens for Responsible Energy (PRM-50-53) ..... 110

North Carolina Public Utility Commission (PRM-50-57) ..... 113

Virginia Electric and Power Company (PRM-50-58)......... 114

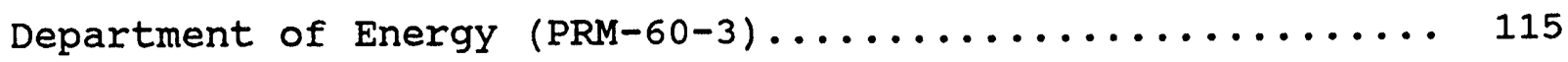

New England Coalition on Nuclear Pollution, Inc.

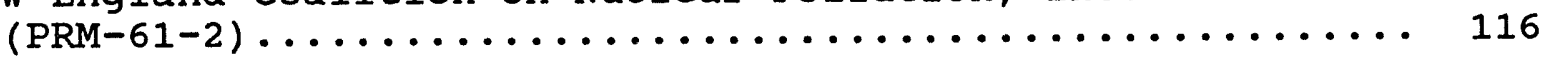

Maryland Safe Energy Coalition (PRM-72-1) ............ 117*

Envirocare of Utah, Inc. $(\mathrm{PRM}-150-2) \ldots \ldots \ldots \ldots \ldots \ldots$

American College of Nuclear Physicians and Society of

Nuclear Medicine $(\mathrm{PRM}-170-3) \ldots \ldots \ldots \ldots \ldots \ldots \ldots$

American Mining Congress $(\mathrm{PRM}-170-4) \ldots \ldots \ldots \ldots \ldots \ldots$

(D) Petitions with deferred action

None 
Preface

The Regulatory Agenda is a quarterly compilation of all rules on which the NRC has recently completed action, or has proposed action, or is considering action, and of all petitions for rulemaking that the NRC has received that are pending disposition.

\section{organization of the Agenda}

The agenda consists of two sections that have been updated through September 30, 1993. Section I, "Rules," includes (A) rules on which final action has been taken since June 30, 1993, the closing date of the last NRC Regulatory Agenda; (B) rules published previously as proposed rules on which the Commission has not taken final action; (C) rules published as advance notices of proposed rulemaking for which neither a proposed nor final rule has been issued; and (D) unpublished rules on which the NRC expects to take action.

Section II, "Petitions for Rulemaking," includes (A) petitions denied or incorporated into final rules since June 30, 1993; (B) petitions incorporated into proposed rules; (C) petitions pending staff review, and (D) petitions with deferred action.

In section I of the agenda, the rules are ordered from the lowest to the highest part within Title 10, Chapter I, of the Code of Federal Regulations (Title 10). If more than one rule appears under the same part, the rules are arranged within that part by date of most recent publication. If a rule amends multiple parts, the rule is listed under the lowest affected part. In section II of the agenda, the petitions are ordered from the lowest to the highest part of Title 10 and are identified with a petition for rulemaking (PRM) number. If more than one petition appears under the same CFR part, the petitions are arranged by PRM numbers in consecutive order within that part of Title 10 .

A Regulation Identifier Number (RIN) has been added to each rulemaking agenda entry. This identification number will make it easier for the public and agency officials to track the publication history of regulatory actions.

The dates listed under the heading "Timetable" for scheduled action by the Commission or the Executive Director for operations (EDO) on particular rules or petitions are considered tentative and are not binding on the commission or 
its staff. They are included for planning purposes only. This Regulatory Agenda is published to provide the public early notice and opportunity to participate in the rulemaking process. However, the NRC may consider or act on any rulemaking proceeding even if it is not included in this Regulatory Agenda.

Rulemakings Approved by the Executive Director for operations (EDO)

The Executive Director for Operations initiated a procedure for the review of the regulations being prepared by staff offices that report to him to ensure that staff resources were being allocated to achieve NRC's regulatory priorities most effectively. This procedure requires EDO approval before staff resources may be expended on the development of any new rulemaking. Furthermore, all existing rules must receive EDO approval prior to the commitment of additional resources.

Those unpublished rules whose further development has been terminated will be noted in this edition of the agenda and deleted from subse dent editions. Rules whose termination was directed subsequent to publication of a notice of proposed rulemaking or an advance notice of proposed rulemaking will be removed from the agenda after publication of a notice of withdrawal. Rules and Petitions for Rulemaking that appear on the agenda for the first time are identified by an asterisk (*).

\section{Public Participation in Rulemaking}

Comments on any rule in the agenda may be sent to the secretary of the Commission, U.S. Nuclear Regulatory Commission, Washington, DC 20555, Attention: Docketing and Service Branch. Comments may also be hand delivered to one white Flint North, 11555 Rockville Pike, Rockville, Maryland, between 7:30 a.m. and $4: 15$ p.m., Federal workdays. Comments received on rules for which the comment period has closed will be considered if it is practical to do so, but assurance of consideration cannot be given except as to comments received on or before the closure dates specified in the agenda.

The agenda and any comments received on any rule listed in the agenda are available for public inspection, and copying for a fee, at the Nuclear Regulatory Commission's Public Document Room, 2120 L Street, NW. (Lower Level), Washington, DC, between 7:45 a.m. and 4:15 p.m. 


\section{Additional Rulemaking Information}

For further information concerning NRC rulemaking procedures or the status of any rule listed in this agenda, contact Betty Golden, Regulations Specialist, Rules Review and Directives Branch, Division of Freedom of Information and Publications Services, office of Administration, U.S. Nuclear Regulatory Commission, Washington, DC 20555, Telephone (301) 492-4268 (persons outside the Washington, DC metropolitan area may call toll-free: 800-368-5642). For further information on the substantive content of any rule listed in the agenda, contact the individual listed under the heading "Agency contact" for that rule. 


\section{I-RULES}

(A) Rules on which final action has been taken 
TITLE:

Procedures Involving the Equal Access to Justice Act: Implementation

RIN :

3150-AAO1

CFR CITATION:

10 CFR $1 ; 10$ CFR 2

\section{ABSTRACT :}

The proposed rule would have implemented the Equal Access to Justice Act (EAJA) by providing for the payment of fees and expenses to certain eligible individuals and businesses that prevail in agency adjudications when the agency's position is determined not to have been substantially justified. This proposed rule was issued by the Commission in 1981. A draft final rule was sent to the Commission in June 1982, but Commission action was suspended pending a decision by the Comptroller General on the availability of funds to pay awards to intervenor parties. Because considerable time passed since this proposed rule was published, the Commission is withdrawing this proposed rule and replacing it with a new proposed rule entitled, "Equal Access to Justice Act: Implementation" (RIN 3150-AE61). This proposed rule was published in the Federal Register on August 2, 1993 (58 FR 41061).

TIMETABLE :

Notice Withdrawing Proposed Action Published 08/02/93 58 FR 41061

LEGAL AUTHORITY:

5 USC 504

EFFECTS ON SMALL BUSINESS AND OTHER ENTITIES: NO

AGENCY CONTACT:

Susan Fonner

Office of the General Counsel

$301 \quad 504-1634$ 


\section{TITLE :}

Radioactive Waste Below Regulatory Concern; Generic Rulemaking

RIN :

$3150-A C 35$

CFR CITATION:

10 CFR 2; 10 CFR 20

ABSTRACT :

The advance notice of proposed rulemaking (ANPRM) was published to request public comment on a proposal to amend NRC regulations to address disposal of radioactive wastes that contain sufficiently low quantities of radionuclides that their disposal does not need to be regulated as radioactive. The Commission has determined that this rulemaking is unnecessary and is withdrawing this action.

TIMETABLE:

Notice of Withdrawal Published 08/24/93 58 FR 44620

LEGAL AUTHORITY:

Pub. L. 99-240

EFFECTS ON SMALL BUSINESS AND OTHER ENTITIES: Undetermined

AGENCY CONTACT:

Robert A. Meck

Office of Nuclear Regulatory Research

$301492-3737$ 
TITLE :

$$
\text { Duplication Fees }
$$

RIN :

$$
\text { 3150-AE79 }
$$

CFR CITATION:

10 CFR 9

ABSTRACT:

The final rule amends the commission's regulations by revising the charges for copying records publicly available at the NRC Public Document Room in Washington, DC. The amendment reflects the change in copying charges resulting from the Commission's award of a new contract for the copying of records.

\section{TIMETABLE :}

Final Action Published 07/20/93 58 FR 38665

Final Action Effective 07/20/93

LEGAL AUTHORITY:

42 USC 2201; 42 USC 5841

EFFECTS ON SMALL BUSINESS AND OTHER ENTITIES: NO

AGENCY CONTACT:

Thomas E. Smith

office of the secretary

$202634-3366$ 
TITLE :

*Access Authorization Fee Schedule for Licensee Personnel

RIN :

3150-AE68

CFR CITATION:

10 CFR 11; 10 CFR 25

ABSTRACT:

The final rule amends the Commission's regulations to revise the fee schedule for background investigations of licensee personnel who require access to National Security Information and/or Restricted Data and access to or control over Special Nuclear Material.

TIMETABLE:

Final Action Published 08/23/93 58 FR 44435

Final Action Effective 09/22/93

LEGAL AUTHORITY:

42 USC 2201; 42 USC 5841

EFFECTS ON SMALL BUSINESS AND OTHER ENTITIES: NO

AGENCY CONTACT: Sandra Schoenmann

Office of Administration

$301 \quad 492-4774$ 
TITLE:

Authorization to Prepare Radiopharmaceutical Reagent Kits and Elute Radiopharmaceutical Generators; Use of Radiopharmaceuticals for Therapy; Extension of Expiration Date

RIN :

3150-AE58

CFR CITATION:

10 CFR $30 ; 10$ CFR 35

ABSTRACT:

The final rule amends the commission's regulations to extend the expiration date of the interim final rule related to the preparation and therapeutic use of radiopharmaceuticals from August 23, 1993, to December 31, 1994 .

TIMETABLE:

Final Action Published

$07 / 22 / 93 \quad 58$ FR 39130

Final Action Effective $08 / 23 / 93$

LEGAL AUTHORITY:

42 USC 2201; 42 USC 5841

EFFECTS ON SMALL BUSINESS AND OTHER ENTITIES: NO

AGENCY CONTACT:

Anthony N. Tse

Office of Nuclear Regulatory Research

$301492-3797$ 
TITLE:

Decommissioning Recordkeeping and License Termination: Documentation Additions

RIN :

$$
3150-A D 98
$$

CFR CITATION:

10 CFR 30; 10 CFR 40; 10 CFR 50; 10 CFR 70; 10 CFR 72

ABSTRACT:

The final rule amends the commission's regulations to require holders of a specific license for possession of certain byproduct material or for independent storage of spent nuclear fuel and high-level radioactive waste to prepare and maintain additional documentation. The documentation must identify all restricted areas where licensed materials and equipment were stored or used, all areas outside of restricted areas where documentation is required under current decommissioning regulations for unusual occurrences or spills, all areas outside of restricted areas where waste has been buried, and all areas outside of restricted areas containing material such that if the license were terminated, the licensee would be required to decontaminate the area or seek special approval for disposal. The final rule also requires licensees to submit specific information at the time of final decommissioning on decontaminated equipment that had been involved in the licensed activity that will remain onsite at the time of license termination.

TIMETABLE :

Final Action Published $07 / 26 / 93 \quad 58$ FR 39628

Final Action Effective 10/25/93

LEGAL AUTHORITY:

42 USC 2201; 42 USC 5841

EFFECTS ON SMALL BUSINESS AND OTHER ENTITIES: YeS

AGENCY CONTACT:

Carl Feldman

Office of Nuclear Regulatory Research

$301492-3883$ 
TITLE :

Certification of Industrial Radiographers

RIN :

3150-AE69

CFR CITATION:

10 CFR $34 ; 10$ CFR 150

ABSTRACT:

The proposed rule would have amended the Commission's regulations pertaining to industrial radiography. This rulemaking is being incorporated into a proposed rule entitled "Radiography and Radiation Safety Requirements for Radiographic operations" (RIN 3150-AEO7). This proposed rule is scheduled to be published in November 1993.

TIMETABLE:

Incorporated into Proposed Rule 09/30/93

LEGAL AUTHORITY:

42 USC 2201; 42 USC 5841

EFFECTS ON SMALL BUSINESS AND OTHER ENTITIES: NO

AGENCY CONTACT:

J. Bruce Carrico

Office of Nuclear Material safety and Safeguards $301 \quad 504-2634$ 
TITLE:

Iridium-192 Wire for Interstitial Treatment of Cancer

RIN :

$3150-A D 46$

CFR CITATION:

10 CFR 35

ABSTRACT :

The proposed rule would have amended the Commission's regulations governing the medical uses of byproduct material. This proposed rule was developed in response to a petition for rulemaking (Docket No. PRM-35-8) submitted by Amersham Corporation. However, in March 1993, the petitioner withdrew the petition for rulemaking. Therefore, this proposed rule is no longer necessary and is being terminated. A Federal Register notice announcing the withdrawal of the petition for rulemaking was published in the Federal Register on August 23, 1993 (58 FR 44466).

TIMIETABLE :

Terminated $08 / 23 / 93$

LEGAL AUTHORITY:

42 USC 2201; 42 USC 5841

EFFECTS ON SMALL BUSINESS AND OTHER ENTITIES: NO

AGENCY CONTACT:

Anthony Tse

Office of Nuclear Regulatory Research

$301 \quad 492-3797$ 
TITLE:

Loss of All Alternating Current Power

RIN :

3150-AE06

CFR CITATION:

10 CFR 50

ABSTRACT:

The proposed rule would have required licensees to test and monitor the reliability of emergency diesel

generators (EDG) against criteria that are consistent with the EDG target levels selected for compliance with the require-ments for station blackout. The commission has determined that this rulemaking is unnecessary and is withdrawing the proposed rule.

TIMETABLE :

Notice of Withdrawal Published $07 / 14 / 93 \quad 58$ FR 37884

LEGAL AUTHORITY:

42 USC 2201; 42 USC 2237; 42 USC 5841; 42 USC 5842;

42 USC 5846

EFFECTS ON SMALL BUSINESS AND OTHER ENTITIES: NO

AGENCY CONTACT:

Aleck Serkiz

office of Nuclear Regulatory Research

301 492-3942 
TITLE:

FSAR Update Submittals

RIN :

3150-AE63

CFR CITATION:

10 CFR 54

ABSTRACT :

The final rule amends the Commission's regulations on power reactor safety in order to apply the requirements that nuclear power plant licensees submit final safety analysis report updates annually or six months after each refueling outage consistently. These amendments will eliminate confusion regarding two references to an existing reporting requirement.

TIMETABLE :

Final Action Published 08/27/93 57 FR 45243

Final Action Effective 09/27/93

LEGAL AUTHORITY:

42 USC $5841 ; 42$ USC $5842 ; 42$ USC 5845

EFFECTS ON SMALL BUSINESS AND OTHER ENTITIES: NO

AGENCY CONTACT:

Claudia M. Craig

Office of Nuclear Reactor Regulation

301 504-1281 
TITLE :

Day Firing Qualifications for Security Personnel at Category I Licensee Fuel Cycle Facilities

RIN :

$3150-A D 30$

CFR CITATION :

10 CFR 73, Appendix H

ABSTRACT :

The final rule amends the commission's regulations to require Tactical Response Team members, armed response personnel, and guards at fuel cycle facilities possessing formula quantities of strategic special nuclear material (Category I licensees) to qualify and annually requalify for use of their assigned weapons using new day firing qualification courses.

TIMETABLE:

Final Action Published 08/31/93 58 FR 45781

Final Action Effective 02/28/94

LEGAL AUTHORITY:

42 USC 2201; 42 USC 5841

EFFECTS ON SMALL BUSINESS AND OTHER ENTITIES: NO

AGENCY CONTACT:

Harry S. Tovmassian

office of Nuclear Regulatory Research

$301492-3634$ 
TITLE:

Adjustment of the Maximum Standard Deferred Premium

RIN :

3150-AE75

CFR CITATION:

10 CFR 140

ABSTRACT:

The final rule amends the Commission's regulations to increase standard deferred premium, presently

established at $\$ 63$ million per reactor per accident (but not to exceed $\$ 10$ million in any one year), to $\$ 75.5$ million per reactor per accident (but not to exceed $\$ 10$ milition in any one year), in accordance with the aggregate percentage change of 19.9 percent in the Consumer Price Index from August 1988 through March 1993.

TIMETABLE:

Final Action Published 08/12/93 58 FR 42851

Final Action Effective 08/20/93

LEGAL AUTHORITY:

42 USC 2201; 42 USC 5841

EFFECTS ON SMALL BUSINESS AND OTHER ENTITIES: NO

AGENCY CONTACT:

Ira Dinitz

Office of Nuclear Reactor Regulation

$301 \quad 504-1289$ 
TITLE:

FY 1991 and FY 1992 Final Rule Implementing the U.S. Court of Appeals Decision and Revision of Fee

Schedules; 100\% Fee Recovery, FY 1993

RIN :

3150-AE4 9

CFR CITATION:

10 CFR 170; 10 CFR 171

ABSTRACT:

The final rule amends the Commission's regulations concerning the licensing, inspection, and annual fees charged to its applicants and licensees. The final rule establishes the fees charged to commission licensees in Fiscal Year 1993. The final rule implements the Omnibus Budget Reconciliation Act of 1990 which requires the NRC to collect approximately 100 percent of its budget authority through fees for fiscal years (FY 1991-1995).

TIMETABLE :

Final Action Published 07/20/93 58 FR 38666

Final Action Effective 08/19/93

LEGAL AUTHORITY:

42 USC 2201; 42 USC 5841; Pub. L. 101-508

EFFECTS ON SMALL BUSINESS AND OTHER ENTITIES: YeS

AGENCY CONTACT:

C. James Holloway, Jr.

office of the Controller $301492-4301$ 
TITLE :

Nuclear Regulatory Commission Acquisition Regulation;

Minor Amendments

RIN :

3150-AE78

CFR CITATION:

48 CFR 2017; 48 CFR 2052

ABSTRACT :

The final rule amends the commission's acquisition regulations governing the procurement of goods and services within the NRC. The final rule revises the duration of contract extensions that the Head of the contracting Activity may approve. The final rule also revises the "Security" clause in Part 2052 to identify the "Changes" clause as the authority under which changes to the commission's security regulations and requirements would be incorporated into a contract.

TIMETABLE:

Final Action Published 09/08/93 58 FR 47220

Final Action Effective 09/08/93

LEGAL AUTHORITY:

42 USC 2201; 42 USC 5841

EFFECTS ON SMALL BUSINESS AND OTHER ENTITIES: NO

AGENCY CONTACT:

Ed Halman

Office of Administration

301 504-1585 
(B) Proposed Rules 
TITLE:

Availability of official Records

RIN :

$3150-A C 07$

CFR CITATION:

10 CFR 2

ABSTRACT :

The proposed amendment would conform the NRC'S

regulations pertaining to the availability of official records to existing case law and agency practice. The amendment would reaffirm that 10 CFR 2.790 (c) provides submitters of information a qualified right to have their information returned upon request. This amendment informs the public of three additional circumstances where information will not be returned to the applicant, i.e., information which has been made available to an advisory committee or was received at an advisory committee meeting, information discussed at an open Commission meeting under the Government in Sunshine Act, and information that is subject to a pending Freedom of Information Act request.

The proposed amendment would also address the NRC's procedures for handling copyrighted information, including reproduction and distribution according to normal agency practice. The NRC, in receiving submittals and making its normal distributions, routinely photocopies submittals, makes microfiche of the submittals, and ensures that these fiche are distributed to the Public Document Room, Local Public Document Rooms, all appropriate internal offices, and made available to the National Technical Information service. This broad distribution and reproduction is made to increase public understanding of the peaceful uses of atomic energy. The proposed rule would not prevent submitters from applying 10 CFR 2.790(b)(1) procedures to information that contains trade secrets or privileged or confidential commercial or financial information (proprietary information) and it is recognized that some information in those categories may be copyrighted. Proprietary information status exempts this material from public disclosure and is not to be confused with handling pursuant to copyright designation. 
TITLE :

Availability of official Records

TIMETABLE :

Proposed Action Published 12/23/92 57 FR 61013

Proposed Action Comment Period Ends 03/08/93

Final Action Published Undetermined

LEGAL AUTHORITY:

42 USC 2201; 42 USC 5841

EFFECTS ON SMALL BUSINESS AND OTHER ENTITIES: NO

AGENCY CONTACT:

Catherine M. Holzle

Office of the General Counsel

$301504-1560$ 
TITLE:

Interim storage of spent Fuel in an Independent spent Fuel storage Installation; Site-Specific License to a Qualified Applicant

RIN :

3150-AE64

CFR CITATION :

10 CFR 2; 10 CFR 72

ABSTRACT:

The proposed rule would amend the Commission's procedures under which the Director of Nuclear Materials Safety and Safeguards can issue a sitespecific license to a qualified applicant for the interi:: storage of spent fuel in an independent spent fuel storage installation (ISFSI) following

satisfactory completion of NRC safety and environmental reviews and after any public hearing on the application. The proposed rule is administrative in nature and would eliminate the need for express Commission authorization for each ISFSI license, but would not affect the scope of NRC review of an ISFSI license application or change the present opportunity for public hearing provided for in the NRC's rules of practice.

TIMETABLE:

Proposed Action Published 06/03/93 58 FR 31478

Proposed Action Comment Period Ends 10/01/93 58 FR 48004

Final Action Published Undetermined

LEGAL AUTHORITY:

42 USC 2201; 42 USC 5841

EFFECTS ON SMALL BUSINESS AND OTHER ENTITIES: NO

AGENCY CONTACT:

C. William Reamer

office of the General Counsel

$301504-1640$ 
TITLE:

Equal Access to Justice Act: Implementation

RIN :

3150-AE61

CFR CITATION:

10 CFR 12

ABSTRACT :

The proposed rule would amend the Commission's regulations by adding new provisions designed to

implement the Equal Access to Justice Act (EAJA). The EAJA provides for the award of fees and expenses to certain individuals and businesses that prevail in agency formal adjudicatory proceedings in which the agency's position is determined not to have been substantially justified. This rule replaces the existing related proposed rulemaking entitled, "Procedures Involving the Equal Access to Justice Act: Implementation" (RIN 3150-AAO1).

\section{TIMETABLE :}

Proposed Action Published 08/02/93 58 FR 41061

Proposed Action Comment Period Ends 09/01/93

Final Action Published 12/00/93

LEGAL AUTHORITY:

42 USC 2201; 42 USC 5841

EFFECTS ON SMALL BUSINESS AND OTHER ENTITIES: NO

AGENCY CONTACT:

Susan Fonner

Office of the General Counsel

$301504-1634$ 
TITLE :

Whistleblower Protection for Nuclear Power Plant Employees

RIN :

$$
3150-A E 50
$$

CFR CITATION:

10 CFR 19; 10 CFR 30; 10 CFR 40; 10 CFR 50; 10 CFR 60;

10 CFR 61; 10 CFR 70; 10 CFR 72; 10 CFR 150

ABSTRACT :

The proposed rule would amend the Commission's regulations by revising certain sections to conform with the nuclear whistleblower protection provisions of the Energy Policy Act of 1992. The new nuclear whistleblower protection provisions of the Energy Policy Act of 1992, which was enacted on October 24, 1992, amend Section 210 of the Energy Reorganization Act of 1974. The legislation extends the period in which to file a claim and extends protection to new classes of employees and employers. Because there were two Section 210's in the Energy Reorganization Act, the new legislation renumbers the whistleblower protection provision as section 211. In addition, the new legislation requires that employers post the whistleblower protection provisions in a prominent place at the work site. These additional requirements and scope changes are being reflected in the proposed rule.

\section{TIMETABLE :}

Proposed Action Published 06/15/93 58 FR 33042

Proposed Action Comment Period Ends 07/15/93

Final Action Published 10/08/93

LEGAL AUTHORITY:

42 USC 2201; 42 USC 5841

EFFECTS ON SMALL BUSINESS AND OTHER ENTITIES: NO

AGENCY CONTACT:

James Lieberman

Office of Enforcement

$301504-2741$ 
TITLE:

Low-Level Waste Manifest Information and Reporting

RIN :

$3150-A D 33$

CFR CITATION:

10 CFR 20; 10 CFR 61

ABSTRACT:

The proposed rule would amend the Commission's regulations to: (1) improve information contained in manifest.s accompanying shipments of waste to low-level waste (LLW) disposal facilities licensed under Part 61; (2) develop a uniform manifest for national use; (3) require that operators of these disposal facilities store manifest information in electronic recordkeeping systems; and (4) require that operators submit, on a machine-readable medium, reports of shipment manifest information.

To ensure safe disposal of $L L W$, the NRC must understand the mechanisms and rates by which radioactivity can be released from $L L W$ and into the environment. To do this, the NRC must understand the chemical, physical, and radiological characteristics of LLW. This task is greatly complicated by the heterogeneous nature of LLW; it exists in a variety of chemical and physical forms and contains roughly 200 different radionuclides in concentrations that can range from a few microcuries to several hundred curies per cubic foot. Each year there are thousands of shipments to LIW disposal sites.

Pursuant to Part 20, a manifest must accompany each shipment of LLW to a disposal facility. Unfortunately, existing manifests do not describe the waste in detail sufficient to ensure compliance with Part 61 performance objectives.

A rulemaking that upgrades shipment manifests, provides for a uniform manifest, and requires disposal site electronic recordkeeping systems and electronic transmittal of data will assure that technical information on LLW is available and in a form which can be used for performance assessments, technical analysis, and other activities and would reduce confusion resulting from multiple manifest forms. A requirement to report electronic manifest information will ensure that the regulatory staff has the ability to perform safety and environmental assessments and to monitor compliance with regulations and license conditions. 
TITLE:

Low-Level Waste Manifest Information and Reporting

ABSTRACT: (CONT)

The rulemaking would facilitate the eventual

development of a complete, detailed national LLW computer data base, if appropriate, that contains information about waste disposed in all LLW sites, those regulated by NRC as well as by Agreement states. The rulemaking, through development of a uniform manifest, would also improve safe and expeditious movement of LLW from generators through processors or collectors to disposal facilities. Emergency accident procedures would be enhanced through use of a single uniform manifest.

The NRC does not expect that the rulemaking will increase disposal costs. The final rule is dependent upon a coordinated rulemaking effort with the Department of Transportation.

TIMETABLE :

Proposed Action Published 04/21/92 57 FR 14500

Proposed Action Comment Period Ends 07/20/92

Final Action Published Undetermined

LEGAL AUTHORITY:

42 USC 2201; 42 USC 5841

EFFECTS ON SMALL BUSINESS AND OTHER ENTITIES: YeS

AGENCY CONTACT:

Mark Haisfield/William Lahs

office of Nuclear Regulatory Research

office of Nuclear Material Safety and Safeguards

$301492-3877 / 301504-2569$ 
TITLE :

Modifications to Fitness-for-Duty Program Requirements

RIN :

3150-AE36

CFR CITATION:

10 CFR 26

ABSTRACT :

The proposed rule would amend the NRC's regulations to modify the current Fitness-for-Duty Program (FFD)

requirements. The proposed amendments would apply to

all Iicensees authorized to construct or operate a

nuclear power reactor and all licensees authorized to possess or transport category I nuclear material. The proposed rule is intended to reduce unnecessary burdens by reducing the random testing rate for licensee employees and to ensure the continued protection of public health and safety.

TIMETABLE:

Proposed Action Published 03/24/93 58 FR 15810

Proposed Action Comment Period Ends 06/22/93

Final Action Published 12/00/93

LEGAL AUTHORITY:

42 USC 2201; 42 USC 5841

EFFECTS ON SMALL BUSINESS AND OTHER ENTITIES: Undetermined

AGENCY CONTACT:

Loren Bush, Jr.

Office of Nuclear Reactor Regulation

$301 \quad 504-2944$ 
TITLE:

Procedures and Criteria for on-site storage of Low-Level Radioactive Waste

RIN :

3150-AE22

CFR CITATION:

10 CFR $30 ; 10$ CFR $40 ; 10$ CFR $50 ; 10$ CFR $70 ; 10$ CFR 72

ABSTRACT:

The proposed rule would amend the Commission's regulations for reactor, material, fuel cycle, and independent spent fuel storage licensees. The proposed rule would establish a regulatory framework containing the procedures and criteria that will apply to on-site storage of low-level radioactive waste (LLW), beyond January 1, 1996. The Commission has determined, under the authority of the Atomic Energy Act of 1954, as amended, that these changes are required because of potential health and safety concerns associated with the increased reliance upon on-site storage of LLW. The proposed rule is intended to support the goals that have been established by the Low-Level Radioactive Waste Policy Amendments Act of 1985.

\section{TIMETABLE :}

Proposed Action Published 02/02/93 58 FR 6730

Proposed Action Comment Period Ends 04/05/93

Final Action Published 12/00/93

LEGAL AUTHORITY:

42 USC 2201; 42 USC 5841

EFFECTS ON SMALL BUSINESS AND OTHER ENTITIES: Undetermined AGENCY CONTACT:

Robert Nelson

office of Nuclear Material Safety and Safeguards $301504-2004$ 
TITLE:

Self-Guarantee as an Additional Financial Assurance Mechanism

RIN :

3150-AE16

CFR CITATION:

10 CFR 30; 10 CFR 40; 10 CFR 50; 10 CFR 70; 10 CFR 72

ABSTRACT:

The proposed rule would amend the Commission's regulations by revising the current decommissioning financial assurance requirements to allow non-electric utility reactor licensees who meet stringent financial criteria tests to provide self-guarantee as a means to comply with the decommissioning regulations. Under the current decommissioning regulations, non-electric utility reactor licensees are permitted to provide financial assurance of decommissioning funds through (1) prepayment or external sinking fund in the form of a trust, escrow account, government fund, certificate of deposit, or deposit of government securities;

(2) surety method or insurance in the form of a surety bond, letter of credit, or line of credit; or (3) parent company guarantee. These funding methods do not permit non-electric utility reactor licensees to provide financial assurance by submitting a selfguarantee that meets or exceeds the criteria for a qualifying parent company guarantee.

TIMETABLE:

Proposed Action Published 01/11/93 58 FR 3515

Proposed Action Comment Period Ends 03/29/93

Final Action Published 11/00/93

LEGAL AUTHORITY:

42 USC 2201; 42 USC 5841

EFFECTS ON SMALL BUSINESS AND OTHER ENTITIES: NO

AGENCY CONTACT:

Clark Prichard

Office of Nuclear Regulatory Research

$301492-3734$ 
TITLE:

Timeliness in Decommissioning of Materials Facilities

RIN :

$3150-A D 85$

CFR CITATION:

10 CFR 30; 10 CFR 40; 10 CFR 70; 10 CFR 72

ABSTRACT :

The proposed rule would amend the Commission's regulations to require decontamination and decommissioning of material facilities within a fixed period of time after cessation of operations.

Current regulations allow material licensees considerable discretion as to the timing of decontamination and decommissioning. This has allowed licensees to remain inactive without decommissioning on the basis that operations may resume sometime in the future. Similarly, licensees are not required to decontaminate promptly, in step-by-step fashion, portions of their facilities that become inactive as their operations evolve. This allows licensees to postpone heavy decommissioning costs by simply continuing sufficient controls, monitoring, and surveillance to meet minimal safety requirements.

The proposed rule would require decontamination and decommissioning of materials facilities within a fixed period of time (e.g., 2-3 years) after cessation of operations. This requirement would be accompanied by a provision that the licensee seek a variance if completion of decontamination or decommissioning within the required times is not technically achievable or if delaying decontamination or decommissioning would , reduce risk to public health and safety or the environment.

The rulemaking will result in publication of specific criteria for timeliness in the decontamination and decommissioning of material facilities. This rulemaking will provide a more substantial planning base for the industry and result in timely decontamination and decommissioning of material facilities. The resulting timely decontamination and decommissioning of materials facilities will reduce the potential radiological risk to the public and the environment from contaminated materials sites. The rulemaking is not expected to substantially affect licensee costs. 
TITLE:

Timeliness in Decommissioning of Materials Facilities

TIMETABLE:

Proposed Action Published 01/13/93 58 FR 4099

Proposed Action Comment Period Ends 03/29/93

Final Action Published 01/00/94

LEGAL AUTHORITY:

42 USC 2201; 42 USC 5841

EFFECTS ON SMALL BUSINESS AND OTHER ENTITIES: NO

AGENCY CONTACT:

Cheryl A. Trottier

Office of Nuclear Regulatory Research

$301492-3640$ 
TITLE :

Requirements for Possession of Industrial Devices Containing Byproduct Material

RIN :

$$
3150-\mathrm{AD} 34
$$

CFR CITATION:

10 CFR $31 ; 10$ CFR 32

ABSTRACT :

The proposed rule would amend the Commission's regulations for the possession of industrial devices containing byproduct material to require device users to report to the NRC initially and then on a periodic basis. The report would indicate that the device is still in use or to whom the device has been transferred. Tre proposed rule would be the most efficient method, considering the number of general licensees and the number of devices currently in use, for assuring that devices are not improperly transferred or inadvertently discarded. The proposed rule is necessary to avoid unnecessary radiation exposure to the public that may occur when an improperly discarded device is included in a batch of scrap metal for reprocessing. The proposed rule would also avoid the unnecessary expense involved in retrieving the manufactured items fabricated from contaminated metal.

TIMETABLE:

Proposed Action Published 12/27/91 56 FR 67011

Proposed Action Comment Period Ends 03/12/92

Final Action Published 11/00/93

LEGAL AUTHORITY:

42 USC 2111; 42 USC 2114; 42 USC 2201

EFFECTS ON SMALL BUSINESS AND OTHER ENTITIES: YES

\section{AGENCY CONTACT:}

Joseph J. Mate

Office of Nuclear Regulatory Research

$301492-3795$ 
TITLE:

Requirements Concerning the Accessible Air Gap for Generally Licensed Devices

RIN :

$$
3150-A D 82
$$

CFR CITATION:

$$
10 \text { CFR } 31 ; 10 \text { CFR } 32
$$

ABSTRACT:

The proposed rule would amend the Commission's regulations to prevent unnecessary radiation exposure to individuals resulting from the use of gauging devices containing radioactive sources. These devices are routinely used for measuring material density, level, weight, moisture, and thickness. The proposed rule would provide for additional regulatory control over devices with both an accessible air gap and radiation levels that exceed specified values.

TIMETABLE :

Proposed Action Published 11/27/92 57 FR 56287 Proposed Action Comment Period Ends 03/29/93

Final Action Published 02/00/94

LEGAL AUTHORITY :

42 USC 2073; 42 USC 2093; 42 USC 2111; 42 USC 2232; 42 USC $2233 ; 42$ USC $2273 ; 42$ USC 5842

EFFECTS ON SMALL BUSINESS AND OTHER ENTITIES: NO

AGENCY CONTACT:

Torre Taylor

Office of Nuclear Regulatory Research

301 492-3746 
TITLE:

Preparation, Transfer for Commercial Distribution, and Use of Byproduct Material for Medical Use

RIN :

$3150-A D 69$

CFR CITATION:

10 CFR 35

ABSTRACT :

The proposed rule would examine the Commission's regulations related to the compounding of radiopharmaceuticals, the use of biologics containing byproduct material, and the medical research uses of radiopharmaceuticals. This rulemaking will address a petition for rulemaking from the American College of Nuclear Physicians and the Society of Nuclear Medicine (PRM-35-9).

TIMETABLE:

Proposed Action Published 06/17/93 58 FR 33396

Proposed Action Comment Period Ends 10/15/93

Final Action Published 06/00/94

LEGAL AUTHORITY:

42 USC $2201 ; 42$ USC 5841

EFFECTS ON SMALL BUSINESS AND OTHER ENTITIES: NO

AGENCY CONTACT:

Anthony Tse

Office of Nuclear Regulatory Research

$301 \quad 492-3797$ 
TITLE :

Licensee Submittal of Data in Computer-Readable Form

RIN :

3150-AE35

CFR CITATION:

10 CFR $40 ; 10$ CFR $72 ; 10$ CFR $74 ; 10$ CFR $75 ; 10$ CFR 150

ABSTRACT :

The proposed rule would amend the Commission's

regulations to require that licensees' submittals

related to special nuclear material transactions be in

computer-readable form. The proposed rule would affect

those licensees possessing reportable quantities of

special nuclear material. The purpose of this proposed amendment is to increase the efficiency of the data

collection process and, at the same time, reduce costs.

TIMETABLE :

Proposed Action Published 01/26/93 58 FR 6098

Proposed Action Comment Period Ends 04/26/93

Final Action Published Undetermined

LEGAI AUTHORITY:

42 USC 2201; 42 USC 5841

EFFECTS ON SMALL BUSINESS AND OTHER ENTITIES: NO

AGENCY CONTACT:

Richard H. Gramann

Office of Nuclear Material Safety and Safeguards $301504-2456$ 
TITLE :

Notification of Spent Fuel Management and Funding Plans by Licensees of Prematurely Shut Down Power Reactors

RIN :

$$
3150-A E 46
$$

CFR CITATION:

$$
10 \text { CFR } 50
$$

ABSTRACT:

The proposed rule would amend the Commission's regulations to clarify the timing of notification to the NRC of spent Fuel Management and Funding Plans by licensees of those nuclear power reactors that have been shut down before the expected end of their operating lives. The proposed rule would require that a licensee submit its notification either within 2 years after permanently ceasing operation of its reactor or no later than 5 years before the reactor operating license expires, whichever event occurs first.

TIMETABLE :

Proposed Action Published 06/30/93 58 FR 34947

Proposed Action Comment Period Ends 09/13/93

Final Action Published 01/00/94

LEGAL AUTHORITY:

42 USC 2201; 42 USC 5841

EFFECTS ON SMALL BUSINESS AND OTHER ENTITIES: NO

AGENCY CONTACT:

Robert Wood

Office of Nuclear Reactor Regulation

$301504-1255$ 
TITLE:

Clarification of Emergency Preparedness Regulations; Exercise Requirements

RIN :

$$
3150-A D 40
$$

CFR CITATION:

10 CFR 50

\section{ABSTRACT :}

The proposed rule would amend the Commission's regulations by clarifying the link between the need for "reasonable assurance that adequate protective measures can and will be taken in the event of a radiological emergency" indicated in $\$ 50.47$ (a) and 16 planning standards outlined in $\$ 50.47(\mathrm{~b})$. In addition, the rulemaking will clarify the term "range of protective actions." other issues to be clarified include monitoring of evacuees, actions for recovery and reentry, notification of the public, evacuation time estimates, and exercise frequency.

TIMETABLE :

Proposed Action Published 06/28/93 58 FR 34539

Proposed Action Comment Period Ends 09/13/93

Final Action Published 07/00/94

LEGAL AUTHORITY:

42 USC $2201 ; 42$ USC 5841

EFFECTS ON SMALL BUSINESS AND OTHER ENTITIES: NO

AGENCY CONTACT:

Michael $T$. Jamgochian

Office of Nuclear Regulatory Research

$301492-3918$ 
TITLE:

Reactor site Criteria; Including seismic and Earthquake Engineering Criteria for Nuclear Power Plants

RIN :

$$
3150-A D 93
$$

CFR CITATION:

10 CFR 50; 10 CFR 52; 10 CFR 100

\section{ABSTRACT :}

The proposed rule would amend the commission's

regulations to update the criteria used in decisions regarding power reactor siting, including geologic, seismic, and earthquake engineering considerations for future nuclear power plants. The proposed rule would allow NRC to benefit from experience gained in the application of the procedures and methods set forth in the current regulation and to incorporate the rapid advancements in the earth sciences and earthquake engineering. The proposed rule primarily consists of two separate changes, namely, the source term and dose considerations, and the seismic and earthquake engineering considerations of reactor siting.

A second phase of this rulemaking action is described in the proposed rule titled, "Acceptability of Plant Performance for Severe Accidents; Scope of Consideration in safety Regulations (RIN 3150-AE38)."

The Commission is also proposing to deny the remaining issue in a petition for rulemaking filed by Free Environment, Inc., et al (PRM-50-20).

\section{TIMETABLE:}

Proposed Action Published 10/20/92 57 FR 47802

Proposed Action Comment Period Ends 06/01/93 58 FR 16377

Final Action Published 01/00/95

LEGAL AUTHORITY:

42 USC 2201; 42 USC 5841

EFFECTS ON SMALL BUSINESS AND OTHER ENTITIES: Undetermined

AGENCY CONTACT:

Leonard Soffer

Office of Nuclear Regulatory Research

$301492-3916$ 
TITLE:

Primary Reactor Containment Leakage Testing for WaterCooled Power Reactors

RIN :

$3150-A A 86$

CFR CITATION:

10 CFR 50; Appendix J

\section{ABSTRACT:}

The proposed rule would update and revise the 1973 criteria for preoperational and periodic pressure testing for leakage of primary containment boundaries of water-cooled power reactors. The commission has determined that this proposed rule is unnecessary and has withdrawn the proposed rule in a staff Requirements Memorandum dated March 1, 1993. A publication date for the notice of withdrawal is undetermined.

TIMETABLE :

Proposed Action Published 10/29/86 51 FR 39538

Proposed Action Comment Period Ends 04/24/87 52 FR 2416

Notice of Withdrawal Published Undetermined

LEGAL AUTHORITY:

42 USC $2133 ; 42$ USC $2134 ; 42$ USC 5841

EFFECTS ON SMALL BUSINESS AND OTHER ENTITIES: NO

AGENCY CONTACT:

Moni Dey

Office of Nuclear Regulatory Research

$301492-3912$ 
TITLE:

Addition of Radon-222 and Technetium-99 Values to Table $\mathrm{s}-3$ and Revisions Resulting from Consideration of Higher-Burnup Fuel

RIN :

3150-AA31

CFR CITATION:

10 CFR 51

ABSTRACT:

Ths proposed rule would amend the Table of Urantum Fuel Cycle Environmental Data (Table s-3) by adding new estimates for potential releases of technetium-99 and radon -222 and by updating other estimates. The proposed rule's narrative explanation (NUREG-1481) also describes the basis for the values contained in Table s-3, explains the environmental effects of these potential releases from the LWR Fuel Cycle, and postulates the potential radiation doses, health effects, and environmental impacts of these potential releases. The proposed rule would also amend 10 CFR 51.52 to modify the enrichment value of $U-235$ and the maximum level of average fuel irradiation (burnup in megawatt-days of thermal power per metric ton of uranium). The narrative explanation also addresses important fuel cycle impacts and the cumulative impacts of the nuclear fuel cycle for the whole nuclear power industry so that it may be possible to consider these impacts genericaliy rather than repeatedly in individual licensing proceedings, thus reducing potential litigation time and costs for both NRC and applicants.

The proposed revision of 10 CFR 51.51 and the narrative explanation was published for public review and comment on March 4, 1981 (46 FR 15154). The final rulemaking was deferred pending the outcome of a suit (Natural Resources Defense Council, et al. v. NRC, No. 74-1486) in the U.S. Circuit Court of Appeals. The U.S. Court of Appeals (D.C. Circuit) decision of April 27, 1982, invalidated the entire Table s-3 rule. The supreme court reversed this decision on June $6,1983$.

The proposed rule and the explanatory narrative for Table $s-3$, NUREG-1481, have been revised to reflict new modeling developments during the time the rulemaiking was deferred. Final action on the Table s-3 rula was held in abeyance until new values for radon-222 and technetium-99 could be added to the table and covered 
TITLE:

Addition of Radon-222 and Technetium-99 Values to Table s-3 and Revisions Resulting from Consideration of Higher-Burnup Fuel

ABSTRACT: (CONT)

in the narrative explanation. The rule is being reissued as a proposed rule because the scope has been expanded to include radiation values for radon-222 and technetium-99 and the narrative explanation has been extensively revised from that published on March 4, 1981 (46 FR 15154).

TIMETABLE :

Proposed Action Published 03/04/81 46 FR 15154

Proposed Action Comment Period Ends 05/04/81

Proposed Action Published Undetermined

LEGAL AUTHORITY:

42 USC 2011; 42 USC 2201; 42 USC $4321 ; 42$ USC 5841; 42 USC 5842

EFFECTS ON SMALL BUSINESS AND OTHER ENTITIES: NO

AGENCY CONTACT:

Stanley Turel

Office of Nuclear Regulatory Research

$301 \quad 492-3739$ 
TITLE:

License Renewal for Nuclear Power Plants; Scope of Environmental Effects

RIN :

$3150-A D 63$

CFR CITATION:

10 CFR 51

ABSTRACT:

The proposed rule would amend the commission's regulations to establish new requirements for environmental review of applications for renewal of nuclear power plant operating licenses. The proposed rule would define the number and scope of environmental issues which would need to be addressed as part of a license renewal application.

TIMETABLE :

ANPRM Published 07/23/90 55 FR 29964

ANPRM Comment Period Ends 10/22/90

Proposed Action Published 09/17/91 56 FR 47016

Proposed Action Comment Period Ends 03/16/92

56 FR 59898

Final Action Published Undetermined

LEGAL AUTHORITY:

42 USC 2201; 42 USC $5841 ; 42$ USC 5842

EFFECTS ON SMALL BUSINESS AND OTHER ENTITIES: NO

AGENCY CONTACT:

Donald P. Cleary

Office of Nuclear Regulatory Research

$301 \quad 492-3936$ 
TITLE:

Operators' Licenses

RIN :

3150-AE39

CFR CITATION:

10 CFR 55

ABSTRACT:

The proposed rule would amend the Commission's regulations to: (1) delete the requirement that each licensed individual pass an NRC-administered requalification examination during the term of license; (2) require that facility licensees submit upon request their annual requalification operating tests and comprehensive requalification written examinations to the NRC for review; and (3) include "Facility Licenses" in the scope of Part 55. The proposed rule would improve operational safety at each facility by redirecting NRC resources to inspect and oversee facility requalification programs rather than conducting requalification examinations. This would reduce both licensee and NRC costs to administer the program.

TIMETABLE:

Proposed Action Published 05/20/93 58 FR 29366

Proposed Action Comment Period Ends 07/19/93

Final Action Published $12 / 00 / 93$

LEGAL AUTHORITY:

42 USC 2201; 42 USC 5841

EFFECTS ON SMALL BUSINESS AND OTHER ENTITIES: NO

AGENCY CONTACT:

Tony DiPalo

Office of Nuclear Regulatory Research

$301 \quad 492-3784$ 
TITLE:

Elimination of Inconsistencies Between NRC Regulations and EPA HLW Standards

RIN :

$3150-\mathrm{ACO} 3$

CFR CITATION:

10 CFR 60

ABSTRACT :

The proposed rule would eliminate several inconsistencies with the EPA standards to be developed for the disposal of HLW in deep geologic repositories. The Nuclear Waste Policy Act of 1982 (NWPA) directs NRC to promulgate criteria for the licensing of HLW geologic repositories. Section 121 (c) of this Act states that the criteria for the licensing of HLW geologic repositories must be consistent with these standards. The proposed rule is needed in order to eliminate several inconsistencies with the EPA standards, thus fulfilling the statutory requirement.

Because the Federal Court invalidated the EPA standards, action on this rule is undetermined. Congress has authorized the National Academy of Sciences to recommend HLW standards to EPA for specific application to Yucca Mountain. The EPA must propose a new standard by 1995.

TIMETABLE:

Proposed Action Published 06/19/86 51 FR 22288

Proposed Action Comment Period Ends 08/18/86

Final Action Published Undetermined

LEGAL AUTHORITY:

42 USC 10101

EFFECTS ON SMALL BUSINESS AND OTHER ENTITIES: NO

AGENCY CONTACT:

Sher Bahadur

Office of Nuclear Regulatory Research

$301492-3775$ 
TITLE :

Clarification of Assessment Requirements for siting Criteria and Performance objectives

RIN :

3150-AE40

CFR CITATION:

10 CFR 60

ABSTRACT:

The proposed rule would amend the Commission's

regulations concerning regulatory requirements for

licensing of high-level waste geologic repositories.

The relationship described in $\$ 60.21$ of the siting criteria in $\$ 60.122$ (defined in terms of potentially adverse and favorable conditions) and the performance objectives in $\$ \$ 60.112$ and 60.113 has been the subject of conflicting interpretations. The proposed rule would resolve the conflicting interpretations of the terms "adequately investigated" and "adequately evaluated" which are used with reference to the potentially adverse conditions in $\$ 60.122$. In addition, the proposed rule would resolve the conflicting interpretations of the relationship of performance assessment and potentially adverse conditions.

The proposed rule would also revise $\$ \$ 60.21$ and 60.122 by removing the analysis requirements from $\$ 60.122$ and placing them in $\$ 60.21$. This would be consistent with other technical aspects of 10 CFR Part 60 . These sections would also be revised to clarify that siting criteria must be appropriately considered in the compliance demonstration for the performance objectives of $\$ \$ 60.112$ and 60.113 . Separate acceptability assessments for individual potentially adverse conditions are not required.

TIMETABLE :

Proposed Action Published 07/09/93 58 FR 36902

Proposed Action Comment Period Ends 10/07/93

Final Action Published $12 / 00 / 94$

LEGAL AUTHORITY:

42 USC 10101; Public Law 97-425

EFFECTS ON SMALL BUSINESS AND OTHER ENTITIES: NO

AGENCY CONTACT:

Mark S. Delligatti

Office of Nuclear Material Safety and Safeguards $301504-2430$ 
TITLE:

Update of Transportation Regulations to Incorporate New Licensing Information

RIN :

$3150-A C 41$

CFR CITATION:

10 CFR 71

ABSTRACT:

The proposed rule would, in conjunction with a corresponding rule change by the U.S. Department of Transportation, update the United States Federal regulations for the safe transportation of radioactive material to incorporate new licensing information developed since 1972. The proposed rule would respond to the need for a: 1) new crush test; 2) new deep immersion test; and 3) new limit on low specific activity material shipments.

TIMETABLE:

Proposed Action Published 06/08/88 53 FR 21550

Proposed Action Comment Period Extended to 03/06/89 53 FR 51281

Proposed Action Comment Period Extended to 60 days after publication of DOT proposed rule 04/04/89 54 FR 13528

DOT Proposed Rule Published 11/14/89 54 FR 47454

Proposed Action Comment Period Ends 02/09/90

Final Action Published 04/00/94

LEGAL AUTHORITY:

42 USC 2073; 42 USC 2093; 42 USC 2111; 42 USC $2232 ; 42$

USC $2233 ; 42$ USC 2273; 42 USC 5842

EFFECTS ON SMALL BUSINESS AND OTHER ENTITIES: NO

AGENCY CONTACT:

Earl P. Easton

Office of Nuclear Material Safety and Safeguards

$301504-2462$ 
TITLE :

Notification of Incidents

RIN :

3150-AE37

CFR CITATION:

10 CFR 72

ABSTRACT:

The proposed rule would amend the Commission's

regulations to add incident reporting requirements to

Part 72 to make it consistent with other regulations in

10 CFR Chapter I. On August 16, 1991 (56 FR 40757),

the Commission published a final rule that deleted

certain incident reporting requirements from Part 20

and replaced them with new incident reporting

requirements in Parts 30,40 , and 70 . However,

incident reporting requirements were not added to part

72. The only alternative to this rulemaking that would

assure that the specified incidents are reported is to

impose these reporting requirements by order or license

condition. However, establishing reporting

requirements by rulemaking is necessary to provide

consistency throughout the Commission's regulations.

TIMETABLE:

Proposed Action Published 09/14/93 58 FR 48004

Proposed Action Comment Period Ends 11/29/93

Final Action Published 08/00/94

LEGAL AUTHORITY:

42 USC 2201; 42 USC 5841

EFFECTS ON SMALL BUSINESS AND OTHER ENTITIES: NO

AGENCY CONTACT:

Naiem S. Tanious

Office of Nuclear Regulatory Research

$301 \quad 492-3878$ 
TITLE:

List of Approved spent Fuel storage Casks: Addition of Cask TN-24

RIN :

3150-AE15

CFR CITATION:

10 CFR 72

ABSTRACT :

The proposed rule would amend the Commission's regulations governing the storage of spent fuel at nuclear power reactor sites in NRC-certified casks under a general license. Five spent-fuel storage casks have been certified and are currently listed in

$\$ 72.214$. The proposed rule would approve and list an additional cask: Cask TN-24 from Transnuclear Inc. A Safety Evaluation Report has been completed for this cask. An operating nuclear power reactor licensee may choose from any of the listed casks to store spent fuel at the reactor site under a general license.

This cask, as well as Cask VSC-24, was included in the proposed rule entitled, "List of Approved Spent Fuel Storage Casks: Additions." The proposed rule was divided into two separate rulemakings (one proposed and one final) due to a delay from Transnuclear, Inc., in allowing the release of proprietary information in accordance with $\$ 2.790$ (c). The final rulemaking, which adds Cask VSC-24, was published in the Federal Register on April 7, 1993 (58 FR 17948).

TIMETABLE :

Proposed Action Published 06/26/92 57 FR 28645

Proposed Action Comment Period Ends 05/17/93 58 FR 19786

Final Action Published 10/18/93

LEGAL AUTHORITY:

42 USC $2201 ; 42$ USC 5846

EFFECTS ON SMALL BUSINESS AND OTHER ENTITIES: Undetermined

AGENCY CONTACT:

Gordon Gundersen

Office of Nuclear Regulatory Research

$301492-3803$ 
TITLE:

Emergency Planning for Independent Spent Fuel storage Facilities (ISFSI) and Monitored Retrievable storage Facilities (MRS)

RIN :

3150-AE17

CFR CITATION :

10 CFR 72

ABSTRACT :

The proposed rule would amend the commission's regulations to provide, as directed by the Nuclear Waste Policy Act of 1982, for the emergency planning licensing requirements for Independent spent Fuel Storage Facilities (ISFSI) and Monitored Retrievable storage Facilities (MRS).

TIMETABLE :

Proposed Action Published 05/24/93 58 FR 29795

Proposed Action Comment Period Ends 11/09/93 58 FR 45463

Final Action Published 08/00/94

LEGAL AUTHORITY:

42 USC 2201; 42 USC 5841

EFFECTS ON SMALL BUSINESS AND OTHER ENTITIES: NO

AGENCY CONTACT:

Michael T. Jamgochian

Office of Nuclear Regulatory Research

$301 \quad 492-3918$ 
TITLE :

Import and Export of Radioactive Waste

RIN :

$$
3150-A D 36
$$

CFR CITATION:

10 CFR 110

\section{ABSTRACT :}

The proposed rule would amend the Commission's licensing requirements to strengthen the commission's controls over radioactive waste coming into and leaving the United states by requiring specific NRC licensing of radioactive waste imports and exports. The proposed rule would help ensure that the transactions are subject to the approval of the U.S. Government and the consent of other involved parties. The proposed amendment would conform U.S. policies with the decision of the General Conference of the International Atomic Energy Agency in September 1990, approving a voluntary Code of Practice to guide Nation states in the development and harmonization of policies and laws on the transboundary shipments of radioactive waste.

Sixteen letters of comment were received from several different sources in response to the proposed rule. These comments are being reviewed by the NRC as it begins to develop the final amendments to the NRC's licensing regulations pertaining to the export and import of radioactive waste.

TIMETABLE :

ANPRM Published 02/07/90 55 FR 4181

ANPRM Comment Period Extended to 04/24/90 55 FR 10786

Proposed Action Published 04/28/92 57 FR 17859

Proposed Action Comment Period Ends 07/13/92

Final Action Published Undetermined

LEGAL AUTHORITY:

42 USC 2201; 42 USC 5841

EFFECTS ON SMALL BUSINESS AND OTHER ENTITLES: Undetermined

\section{AGENCY CONTACT:}

Ronald D. Hauber

Office of International Programs

$301 \quad 504-2344$ 
TITLE:

Specific Licensing of Exports of Certain AlphaEmitting Radionuclides and Byproduct Material

RIN :

3150-AE31

CFR CITATION:

10 CFR 110

\section{ABSTRACT :}

The proposed rule would amend the Commission's regulations to conform with the export control guidelines of the multilateral Nuclear Suppliers Group (NSG) and of the International Atomic Energy List of the Coordinating Committee for Multilateral Export Controls (COCOM), in which the United States participates, and treaty obligations between the United States and Canada. The proposed rule would amend general license regulations for the export of dispersed tritium, bulk tritium, americium-242m, californium-249, californium-251, curium-245, curium-247, and 16 different alpha-emitting radionuclides, including compounds and mixtures containing these radionuclides with a total alpha activity of 1 curie per kilogram or greater. In regard to the radionuclides, devices containing less than 100 millicuries of alpha activity per device would be exempt. Other exports of these alpha-emitting radionuclides would continue to be generally licensed for member states of the NSG, but would require specific licensing to other countries. Each exporter covered by these regulations would have to meet the new requirements, as well as existing regulations.

The proposed rule would also clarify Appendix A to Part 110 , covering nuclear reactor equipment under the NRC licensing authority, to aid exporters and U.S. export regulators in determining the reactor equipment under NRC jurisdiction.

TIMETABLE :

Proposed Action Published 03/17/93 58 FR 14344

Proposed Action Comment Period Ends 04/16/93

Final Action Published Undetermined

LEGAL AUTHORITY:

42 USC 2201; 42 USC 5841

EFFECTS ON SMALL BUSINESS AND OTHER ENTITIES: Yes 
TITLE :

Specific Licensing of Exports of Certain AlphaEmitting Radionuclides and Byproduct Material

\section{AGENCY CONTACT:}

Elaine 0 . Hemby

Office of International Programs

$301504-2341$ 
TITLE:

Criteria for an Extraordinary Nuclear Occurrence

RIN :

$$
3150-\mathrm{AB} 01
$$

CFR CITATION:

10 CFR 140

\section{ABSTRACT:}

The proposed rule would revise the criteria for an extraordinary nuclear occurrence (ENO) to eliminate the problems that were encountered in the Three Mile Island ENO determination. The revised criteria should be established in the event they are needed.

There are no alternatives to this rulemaking. The current ENO criteria are already codified in subpart $E$ of 10 CFR Part 140. The only way to modify these criteria, as this rule seeks to do, is through rulemaking. The final rule will also respond to PRM$140-1$.

TIMETABLE:

Proposed Action Published 04/09/85 50 FR 13978

Proposed Action Comment Period Ends 09/06/85

Final Action Published Undetermined

LEGAL AUTHORITY:

42 USC $2201 ; 42$ USC 2210; 42 USC $5841 ; 42$ USC 5842

EFFECTS ON SMALL BUSINESS AND OTHER ENTITIES: NO

AGENCY CONTACT:

Alan K. Roecklein

Office of Nuclear Regulatory Research

$301 \quad 492-3740$ 
TITLE:

Reasserting NRC's Sole Authority for Approving onsite

Low-Level Waste Disposal in Agreement states

RIN :

$3150-A C 57$

CFR CITATION:

10 CFR 150

ABSTRACT :

The proposed rule would establish NRC as the sole authority for approving onsite disposal of very lowlevel waste at all NRC-11censed reactors and at part 70 facilities. The NRC staff has recommended that this proposed rulemaking be withdrawn.

TIMETABLE:

Proposed Action Published 08/22/88 53 FR 31880

Proposed Action Comment Period Ends 10/21/88

Notice of Withdrawal Published Undetermined

LEGAL AUTHORITY:

42 USC 2201; 42 USC 2021; 42 USC 5841

EFFECTS ON SMALL BUSINESS AND OTHER ENTITIES: NO

AGENCY CONTACT:

Joseph J. Mate

Office of Nuclear Regulatory Research

301 492-3795 
TITLE:

*Restoration of Generic Exemption from Annual Fees for Nonprofit Educational Institutions

RIN :

$$
\text { 3150-AE83 }
$$

CFR CITATION:

10 CFR 171

ABSTRACT:

The proposed rule would amend the Commission's regulations by reinstating the exemption from annual fees for nonprofit educational institutions which was revoked August 19, 1993, the effective date of the FY 1993 fee rule (July 20, 1993; 58 FR 38666). This proposed rule responds to a petition for reconsideration of the July 20, 1993, final rule filed by Cornell and eleven other universities that was granted by the commission.

TIMETABLE:

Proposed Action Published 09/29/93 58 FR 50859 Proposed Action Comment Period Ends 10/29/93 Final Action Published $12 / 00 / 93$

LEGAL AUTHORITY:

42 USC 5841; Pub. I. 101-508

EFFECTS ON SMALL BUSINESS AND OTHER ENTITIES: NO

AGENCY CONTACT:

L. Michael Rafky

office of the General Counsel

$301504-1606$ 
(C) Advance Notlces of Proposed Rulemaking

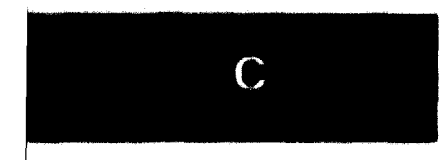


TITLE :

Comprehensive Quality Assurance in Medical Use and a standard of Care

RIN :

$3150-A C 42$

CFR CITATION:

10 CFR 35

\section{ABSTRACT :}

The advance notice of proposed rulemaking (ANPRM) was published to request public comment on the extent to which, in addition to the basic quality assurance procedures (being addressed by another rulemaking action, entitled "Preparation, Transfer for Commercial Distribution, and Use of Byproduct Material for Medical Use" (RIN No. 3150-AD69), a more comprehensive quality assurance requirement is needed and invites advice and recommendations on about 20 questions that will have to be addressed in the rulemaking process. The purpose of this rulemaking action is to address each source of error that can lead to a misadministration.

TIMETABLE:

ANPRM Action Published 10/02/87 52 FR 36949

ANPRM Comment Period Ends $12 / 31 / 87$ 52 FR 36949

Proposed Action Published Undetermined

LEGAL AUTHORITY:

42 USC 2111; 42 USC 2201; 42 USC 5841

EFFECTS ON SMALL BUSINESS AND OTHER ENTITIES: NO

AGENCY CONTACT:

Anthony Tse

Office of Nuclear Regulatory Research

$301 \quad 492-3797$ 
TITLE:

Licensing of Source Material

RIN :

$3150-A E 33$

CFR CITATION:

10 CFR 40

\section{ABSTRACT:}

The advance notice of proposed rulemaking (ANPRM) was published to request public comment on contemplated amendments to the commission's regulations governing the licensing of source material and mill tailings. The contemplated rulemaking would consider revisions to improve the control of source material through more specific regulation and to incorporate the revised standards for protection against radiation.

Fifteen comment letters were received on the ANPRM. The comments are being reviewed by the commission in developing a proposed rulemaking. Based on the comments received and on the status of related activities and priority for addressing the various issues being considered, a tentative approach to rulemaking has been developed. Depending on the nature and extent of comments received, a two step rulemaking may be initiated starting with a simple rule pertaining to the licensing and reporting requirements of distributors of products and materials used by exempt persons and general licensees (phase I). The ANPRM stated that the Commission would consider whether to address the issues related to mills and mill tailings in a separate rulemaking. The options are being considered in place of a single comprehensive rulemaking. In addition, the separate rule entitled, "Reporting Requirements for Transfer of Products to Persons Exempt from Licensing Requirements" (RIN 3150AE28), is being considered for incorporation into the phase I rule. This rule was intended to revise existing reporting requirements pertaining to the distribution of exempt byproduct material. This phase I rule would provide for consistent reporting requirements for the distribution to exempt persons of both byproduct material and source material.

\section{TIMETABLE :}

ANPRM Published 10/28/92

ANPRM Comment Period Ends

Proposed Action Published

57 FR 48749

$01 / 26 / 93$

Undetermined 
TITJE:

Licensing of Source Material

LEGAL AUTHORITY:

42 USC 2201; 42 USC 5841

EFFECTS ON SMALI BUSINESS AND OTHER ENTITIES: Undetermined AGENCY CONTACT:

Catherine R. Mattsen

Office of Nuclear Regulatory Research

$301 \quad 492-3638$ 
TITLE:

Acceptance of Products Purchased for Use in Nuclear Power Plant Structures, systems, and Components

RIN :

$3150-A D 10$

CFR CITATION:

10 CFR 50

ABSTRACT:

The advance notice of proposed rulemaking (ANPRM)

was published to request public comment on the need for additional regulatory requirements and to obtain an improved understanding of alternatives to regulatory requirements. Based upon comment analysis, the staff recommended to the commission that this rule be withdrawn. The Commission has approved withdrawal of this rulemaking.

Recent inspections and discussions with the industry and licensees indicate that there is still some disagreement between industry and the NRC staff regarding commercial grade procurement and dedication. The NRC staff has conducted meetings with the industry and individual licensees to resolve the areas of disagreement. Final issuance of the notice of action will follow resolution of the areas of disagreement.

\section{TIMETABLE :}

ANPRM Published 03/06/89 54 FR 9229

ANPRM Comment Period Ends 07/05/89

Notice of Withdrawal Published Undetermined

LEGAL AUTHORITY:

42 USC 2201; 42 USC 5841

EFFECTS ON SMALL BUSINESS AND OTHER ENTITIES: YeS

AGENCY CONTACT:

Leif $\mathrm{J}$. Norrholm

Office of Nuclear Reactor Regulation

$301504-0961$ 
TITLE :

Acceptability of Plant Performance for Severe

Accidents; Scope of Consideration in Safety Regulations

RIN :

3150-AE38

CFR CITATION:

10 CFR 50

\section{ABSTRACT :}

The advance notice of proposed rulemaking (ANPRM) was published to request public comment on amendment of the Commission's regulations to decouple source term and dose calculations from reactor siting and to permit the use of updated source term insights for future light water reactors. The NRC is presently in the process of reviewing advanced reactor designs. The DOE has also indicated that it intends to seek review for an early site permit, as permitted by 10 CFR Part 52 , in 1993.

This rulemaking action comprises two phases. The first phase is described in the proposed rule titled, "Reactor Site Criteria; Including seismic and Earthquake Engineering Criteria for Nuclear Power Plants (3150-AD93)." The second phase will consist of the issuance of an ANPRM, followed by a final revision of 10 CFR Part 50 to incorporate updated source term and severe accident research insights into plant design requirements for future light water reactors. The intent of this second phase of rulemaking is expected to provide additional requirements for future light water reactors regarding severe accident prevention and mitigation, and is expected to substantially reduce the risks from these events.

TIMETABLE :

ANPRM Published 09/28/92 57 FR 44513

ANPRM Public Comment Period Ends 12/28/92

Proposed Action Published Undetermined

LEGAL AUTHORITY:

42 USC 2201: 42 USC 5841

EFFECTS ON SMALL BUSINESS AND OTHER ENTITIES: Undetermined

AGENCY CONTACT:

Leonard Soffer

Office of Nuclear Regulatory Research

$301 \quad 492-3916$ 
TITLE :

NRC Fee Policy

RIN :

$3150-A E 54$

CFR CITATION:

10 CFR 170, 10 CFR 171

ABSTRACT :

The advance notice of proposed rulemaking (ANPRM) was published to request public comment on changes to NRC's fee policy and associated legislation. This action responds to the requirements of the Energy Policy Act of 1992 that the NRC review its policy for assessment of annual fees, solicit public comment on the need for changes to this policy, and recommend to the congress the changes in existing law that the NRC finds are needed to prevent the placement of an unfair burden on NRC licensees. The NRC is also including in this rulemaking a petition for rulemaking that was submitted by the American Mining Congress (PRM-170-4). This petition for rulemaking requests that the NRC conduct a rulemaking to evaluate its fee policy. Because the issues raised by the petitioner concern the same subjects as the fee policy review, the NRC is including the petition in this Federal Register notice.

TIMETABLE:

ANPRM Published 04/19/93 58 FR 21116

ANPRM Comment Period Ends 08/18/93 58 FR 39174

Proposed Action Published Undetermined

LEGAL AUTHORITY:

42 USC $2214 ;$ Pub. L. 102-486

EFFECTS ON SMALL BUSINESS AND OTHER ENTITIES: NO

AGENCY CONTACT:

C. James Holloway, Jr.

Office of the Controlier

$301492-4301$ 
(D) Unpublished Rules 
TITLE:

Supplemental standards of Ethical Conduct for

Employees of the Nuclear Regulatory Commission

RIN :

3150-AE60

CFR CITATION:

10 CFR 0

ABSTRACT:

The final rule would amend the Commission's regulations by issuing provisions applicable to NRC employees that would supplement the Standards of Ethical Conduct issued by the office of Government Ethics (OGE). These regulations would address outside employment and security ownership by NRC employees. The NRC must obtain OGE concurrence before the rule can be published.

TIMETABLE :

Final Action Published Undetermined

LEGAL AUTHORITY:

42 USC 2201; 42 USC 5841

EFFECTS ON SMALL BUSINESS AND OTHER ENTITIES: NO

AGENCY CONTACT:

L. Michael Rafky

office of the General Counsel

$301504-1606$ 
TITLE:

Revised Rules of Practice for Domestic Licensing Proceedings

RIN :

$3150-A B 66$

CFR CITATION:

10 CFR 0; 10 CFR 1; 10 CFR 2; 10 CFR 9; 10 CFR 50

ABSTRACT :

The proposed rule would shorten and simplify existing Commission procedural rules applicable to domestic licensing proceedings by comprehensively restating, revising, and reorganizing the statement of those rules to reflect current practice. The changes in this proposed rule would enable the Commission, directly and through its adjudicatory offices, to render decisions in a more timely fashion, eliminate the stylistic complexity of the existing rules, and reduce the burden and expense to the parties participating in agency proceedings. In 1987, the Commission deferred consideration of this proposal, which would have revised the Commission's procedural rules governing the conduct of all adjudicatory proceedings other than export licensing proceedings under 10 CFR Part 110, pending consideration of other, more limited revisions to the rules of practice. In 1989, former Chairman Zech requested that this proposed rule be updated for reconsideration by the commission, and more recently, the Administrative Conference of the United States has drafted Model Rules.

TIMETABLE:

Proposed Action Published 09/00/94

Final Action Published 12/00/94

LEGAL AUTHORITY:

42 USC 2201; 42 USC 2231; 42 USC $2241 ; 42$ USC 5841; 5 USC 552

EFFECTS ON SMALL BUSINESS AND OTHER ENTITIES: NO

AGENCY CONTACT:

Lee S. Dewey

Atomic Safety and Licensing Board Panel

$301492-7787$ 
TITLE:

*Statement of Organization and General Information; Minor Amendments

RIN :

$3150-A E 86$

CFR CITATION:

10 CFR 1

ABSTRACT:

The final rule would amend the commission's regulations to reflect the reconstitution of the office of the Licensing Support Systems Administrator as an organizational unit of the office of Information Resources Management and the transfer of the responsibility for administering the Licensing support System from the Commission staff to the office of the Executive Director for operations. This final rule also reflects the creation of the office of Policy Planning.

TIMETABLE:

Final Action Published 05/00/94

LEGAL AUTHORITY:

42 USC 2201; 42 USC 5841

EFFECTS ON SMALL BUSINESS AND OTHER ENTITIES: NO

AGENCY CONTACT:

Alzonia Shepard

Office of Administration

$301 \quad 492-7651$ 


\section{TITLE :}

*Withholding of Documents

RIN :

$$
\text { 3150-AE89 }
$$

CFR CITATION:

10 CFR 2

\section{ABSTRACT :}

The proposed rule would amend the Commission's regulations to address documents that are submitted with regard to an enforcement proceeding, including an inspection or investigation. Under the proposed rule, a document would be released to the NRC's Public Document Room (PDR), if the information submitted forms a part of the basis for a decision regarding enforcement action except for limited specific privacy material. Licensees may request that the NRC withhold information as being confidential, privileged, or subject to other bases for withholding from release to the public. If the NRC does not grant the request for withholding, it must provide the submitter with an opportunity to request that the document be returned to them rather than placed in the PDR.

TIMETABLE :

Proposed Action Published 07/00/94

LEGAL AUTHORITY:

42 USC $2201 ; 42$ USC 5841

EFFECTS ON SMALL BUSINESS AND OTHER ENTITIES: NO

\section{AGENCY CONTACT:}

Geoffrey D. Cant

Office of Enforcement

$301504-3283$ 
TITLE:

Informal Hearing Procedures for Materials Licensing Adjudications

RIN :

3150-AE67

CFR CITATION:

10 CFR 2

ABSTRACT:

The proposed rule would amend the Commission's regulations to provide that requests for hearing in certain materials license proceedings be filed within 30 days of actual notice of the amendment application. The proposed rule would eliminate an ambiguous provision in the commission's current regulations and would ensure that hearing requests are filed as promptly as possible in order to resolve any concerns or objections to the pending application in a timely manner.

\section{TIMETABLE :}

Proposed Action Published Undetermined

LEGAL AUTHORITY:

42 USC 2201; 42 USC 5841

EFFECTS ON SMALL BUSINESS AND OTHER ENTITIES: NO

AGENCY CONTACT:

Marjorie Nordlinger

office of the General counsel

301 504-1634 
TITLE:

Discrimination on the Basis of Sex

RIN :

$3150-A D 50$

CFR CITATION:

10 CFR 2; 10 CFR 19

ABSTRACT :

The final rule would amend the commission's regulations dealing with discrimination against persons who, on the grounds of sex, are excluded from participation in, denied the benefits of, or subjected to discrimination under any program or activity licensed by the NRC. The Commission has decided that section 401 of the Energy Reorganization Act, which prohibits sex discrimination, applies only to the Commission and does not apply to NRC licensees or applicants. Because this decision invalidates 10 CFR 19.32 and 10 CFR 2.111, action is being taken to amend these sections and to incorporate appropriate language to clarify that these sections do not apply to licensee employees.

TIMETABLE:

Final Action Published Undetermined

LEGAL AUTHORITY:

42 USC 2201; 42 USC 5841

EFFECTS ON SMALL BUSINESS AND OTHER ENTITIES: NO

AGENCY CONTACT:

Markley L. Au

Office of Nuclear Regulatory Research

$301 \quad 492-3749$ 
TITLE :

Revision of Specific Exemptions

RIN :

$3150-A D 83$

CFR CITATION:

10 CFR 9

\section{ABSTRACT:}

The proposed rule would amend the Commission's regulations pertaining to specific Privacy Act exemptions. This proposed rule would add exemption (j) (2) of the Privacy Act to the regulations that describe exempt systems of records. These amendments would make NRC's regulations consistent with the majority of statutorily appointed Inspectors General and would clearly link each system of records to the specific exemption(s) of the Privacy Act under which each system is exempt.

TIMETABLE:

Proposed Action Published Undetermined

LEGAL AUTHORITY:

42 USC $2201 ; 42$ USC 5841

EFFECTS ON SMALL BUSINESS AND OTHER ENTITIES: NO

AGENCY CONTACT:

Sarah Wigginton

Office of Administration

$301492-7752$ 
TITLE :

*Radiation Protection Requirements; Amended

Definitions and Criteria

RIN :

3150-AE80

CFR CITATION:

10 CFR 19; 10 CFR 20

ABSTRACT:

The proposed rule would amend the Commission's regulations by (1) deleting the term "Controlled area", (2) revising the definition of "Occupational dose" to delete reference to the "restricted area" to clarify that the occupational dose limit and associated provisions such as training and badging requirements apply to workers who are exposed to radiation and/or radioactive material when engaged in licensed activities regardless of whether those activities are in a restrictive area, and (3) revising 10 CFR 19.12, to ensure that training commensurate with the hazards present will be provided to all workers who become occupationally exposed, not just individual who will be working in or frequenting any portion of a restricted area. This rule would neither restrict a licensee's ability to control access to areas for purposes other than radiation protection, such as for security reasons, nor will it permit members of the public to receive exposures in excess of the public dose limit even if permitted access to a restricted area.

TIMETABLE:

Proposed Action Published 12/00/93

Final Action Published 08/00/94

LEGAL AUTHORITY:

42 USC $2073 ; 42$ USC 2093; 42 USC 2095; 42 USC 2111; 42

USC $2133 ; 42$ USC $2134 ; 42$ USC $2201 ; 42$ USC $2236 ; 42$ USC $2282 ; 42$ USC $5841 ; 42$ USC $5842 ; 42$ USC $5846 ; 42$ USC $5851 ; 42$ USC $10155 ; 42$ USC 10161

EFFECTS ON SMALL BUSINESS AND OTHER ENTITIES: NO

AGENCY CONTACT:

Alan K. Rocklein

Office of Nuclear Regulatory Research

$301492-3740$ 
TITLE :

Radiological Criteria for Decommissioning of Nuclear Facilities

RIN :

$3150-\mathrm{AD} 65$

CFR CITATION:

10 CFR 20

\section{ABSTRACT :}

The proposed rule would amend the Commission's regulations to codify the basic principles and radiological criteria which would allow decommissioned lands and structures to be released for unrestricted public use. In the final rule entitled, "General Requirements for Decommissioning Nuclear Facilities" (53 FR 24018; June 27, 1988), the need and urgency for guidance with respect to residual contamination criteria was expressed. At that time, it was anticipated that an interagency working group organized by the Environmental Protection Agency would develop necessary Federal guidance. However, in the absence of significant progress by the interagency working group, the Commission has directed that the NRC expedite rulemaking because the requirements, once final, will provide licensees with an incentive to complete site decommissionings.

The proposed rule would establish basic radiological criteria for release of lands and structures. Measurables, in the form of surface and volume radioactivity concentrations and site radioactivity inventory values, would be provided in supporting regulatory guidance. These combined activities should benefit the public, industry, and the NRC by providing a risk-based framework upon which decommissioning activities and license terminations can be accomplished. The framework will ensure adequate protection of public health and safety and identify residual radioactivity criteria upon which licensees can confidently develop reasonable and responsible decommissioning plans.

\section{TIMETABLE:}

Proposed Action Published 06/00/94

Final Action Published 06/00/95 
TITIS:

Radiological Criteria for Decommissioning of Nuclear Facilities

LEGAL AUTHORITY:

42 USC 2201; 42 USC 5841

EFFECTS ON SMALL BUSINESS AND OTHER ENTITIES: YES

AGENCY CONTACT:

James Malaro

Office of Nuclear Regulatory Research

$301492-3764$ 
TITLE:

*Disposal by Release into Sanitary Sewerage

RIN :

3150-AE90

CFR CITATION:

10 CFR 20

\section{ABSTRACT :}

The advance notice of proposed rulemaking would request public comment, information and recommendations on contemplated amendments to the commission's regulations governing the release of radionuclides from licensed nuclear facilities into sanitary sewer systems. The commission believes that by incorporating current sewer treatment technologies the contemplated rulemaking would improve the control of radioactive materials released to sanitary sewer systems by licensed nuclear facilities.

\section{TIMETABLE:}

Proposed Action Published 03/00/95

LEGAL AUTHORITY :

42 USC 2201; 42 USC 5841

EFFECTS ON SMALL BUSINESS AND OTHER ENTITIES: NO

AGENCY CONTACT:

George Powers

Office of Nuclear Regulatory Research

301 492-3747 
TITLE:

Release Criteria for Patients Administered Radioactive Materials

RIN :

$3150-A E 41$

CFR CITATION:

10 CFR 20; 10 CFR 35

ABSTRACT :

The proposed rule would amend the Commission's

regulations to revise the patient release criteria

contained in $10 \mathrm{CFR} 35.75$, and the applicability of the dose limits for members of the public in $10 \mathrm{CFR}$ 20.1301 .

The commission has received two petitions for rulemaking, PRM-20-20 and PRM-35-10, to amend its regulations regarding radiation exposure that individuals may receive from patients who have been medically administered radioactive materials, and the criteria under which this patient may be released from confinement. The petitioners believe that the current requirements of Parts 20 and 35 would cause patients to be confined unnecessarily beyond the time needed for medical reasons.

TIMETABLE:

Proposed Action Published 12/00/93

Final Action Published 11/00/94

LEGAL AUTHORITY:

42 USC 2201; 42 USC 5841

EFFECTS ON SMALL BUSINESS AND OTHER ENTITIES: NO

AGENCY CONTACT:

Stewart Schneider

Office of Nuclear Regulatory Research

$301492-3588$ 
TITLE :

*NRC Operations Center; Commercial Telephone Number Change

RIN :

$3150-A E 84$

CFR CITATION:

10 CFR 20; 10 CFR 21; 10 CFR 30; 10 CFR 35; 10 CFR $40 ;$

10 CFR 50; 10 CFR 70; 10 CFR 72; 10 CFR 73

ABSTRACT:

The final rule would amend the commission's regulations by changing the current commercial telephone number at the NRC Operations center. The new phone number will be determined at a later date. The NRC is scheduled to move its operations Center from the Maryland National Bank building in Bethesda, Maryland, to the Two White Flint North building in Rockville, Maryland, in June 1994 .

TIMETABLE:

Final Action Published 05/00/94

LEGAL AUTHORITY:

42 USC 2201; 42 USC 5841

EFFECTS ON SMALL BUSINESS AND OTHER ENTITIES: NO

AGENCY CONTACT:

Jean Trefethen

Office of Analysis and Evaluation of Data

$301492-7280$ 


\section{TITLE:}

Clarification of Reporting of Defects and Noncompliance for Materials Facilities

RIN :

3150-AE18

CFR CITATION:

10 CFR 21

ABSTRACT:

The proposed rule would amend the Commission's regulations concerning the reporting of defects and noncompliance to clarify the applicability of these provisions to materials and fuel cycle licensees. Because of the wide diversity in the types of licensees covered under these regulations, the requirements have been misinterpreted by the licensees. The proposed rule would clearly define the applicability of these provisions to the different types of licensees and would take into account the differences between different classes of licensees. The proposed rule is being developed in response to an NRC internal audit and to a parallel review of these regulations as they apply to materials licensees.

TIMETABLE:

Proposed Action Published 01/00/94

Final Action Published 11/00/94

LEGAL AUTHORITY:

42 USC 2201; 42 USC 5846

EFFECTS ON SMALL BUSINESS AND OTHER ENTITIES: YES

AGENCY CONTACT:

Markley I. Au

Office of Nuclear Regulatory Research

$301492-3749$ 
TITLE:

Reporting Requirements for Transfer of Products to Persons Exempt from Licensing Requirements

RIN :

3150-AE28

CFR CITATION:

10 CFR 32

\section{ABSTRACT :}

The proposed rule would amend the Commission's

regulations to reinstate the annual reporting

requirement for transfer of products containing small quantities of radioactive material to persons exempt from licensing requirements.

Submittal of transfer reports on a 5-year reporting basis has made it difficult for the NRC staff to identify trends in distribution of materials to persons exempt from licensing requirements. Reinstating the annual reporting requirement would provide the NRC with more complete and accurate information on exemptions granted under $10 \mathrm{CFR}$ Part 30 and improve the Commission's capability to assess potential effects of aggregated exposures to the public from a number of exempted practices.

A variation on the use of a threshold which may be considered in this rulemaking would be to exempt those licensees having no transfers during the reporting period from reporting requirements.

TIMETABLE :

Proposed Action Published Undetermined

Final Action Published Undetermined

LEGAL AUTHORITY:

42 USC 2201; 42 USC 5841

EFFECTS ON SMALI BUSINESS AND OTHER ENTITIES: NO

AGENCY CONTACT:

Frank Cardile

Office of Nuclear Regulatory Research

$301 \quad 492-3774$ 
TITLE:

Radiography and Radiation Safety Requirements for Radiography operations

RIN :

3150-AE07

CFR CITATION:

10 CFR 34

ABSTRACT:

The proposed rule would amend the Comnission's regulations on licenses for radiography and radiation safety requirements for radiographic operations. The proposed rule would revise 10 CFR Part 34 to clarify the requirements in $\$ 34.27$ and conform Part 34 with the approach developed by the conference of Radiation Control Program Directors, Inc. (Part $E$ of the "Suggested State Regulations for Control of Radiation"), and the state of Texas in Part 31 of the Texas Regulations for Control of Radiation. Comments and suggestions from regulatory groups, users, and manufacturers will be considered in the overall revision. The NRC will also consult Canadian atomic energy control regulations that relate to radiography. The proposed rule is necessary because of frequent misinterpretations of the provisions of Part 34 and the need to clarify the requirements of 10 CFR 34.27. The staff is currently preparing an options paper which will examine the issues, set priorities, and provide direction for the rulemaking proposed. This proposed rule would also respond to a petition for rulemaking from International Union of operating Engineers - Local No. 2 (PRM-34-4).

TIMETABLE :

Proposed Action Published 12/00/93

Final Action Published 11/00/94

LEGAL AUTHORITY:

42 USC 2201; 42 USC 5841

EFFECTS ON SMALL BUSINESS AND OTHER ENTITIES: YES

AGENCY CONTACT:

Donald Nellis

Office of Nuclear Regulatory Research

$301492-3628$ 
TITLE :

Administration of Byproduct Material or Radiation to Patients Who May Be Pregnant or Breast-Feeding

RIN :

$$
\text { 3150-AE4 } 4
$$

CFR CITATION:

10 CFR 35

\section{ABSTRACT :}

The proposed rule would amend the commission's regulations concerning the medical use of byproduct material. The proposed rule would require medical use licensees to have policies and procedures designed to avoid unintended radiation exposures to an embryo, fetus, or a breast-feeding child. The proposed rule would also require reporting of these events.

TIMETABLE :

Proposed Action Published 03/00/94

LEGAL AUTHORITY :

42 USC $2111 ; 42$ USC $2112 ; 42$ USC 2201; 42 USC 2232; 42 USC $2233 ; 42$ USC $2236 ; 42$ USC 2282

EFFECTS ON SMALL BUSINESS AND OTHER ENTITIES: No

AGENCY CONTACT:

Samuel Z. Jones

Office of Nuclear Regulatory Research

$301 \quad 492-3738$ 
TITLE:

Design and Performance Criteria for Sealed Sources Used in Well Logging

RIN :

$3150-A E 24$

CFR CITATION:

10 CFR 39

ABSTRACT :

The proposed rule would amend the Commission's

regulations governing well logging operations. The proposed rule would allow the continued use of sealed sources that were approved by accepted prototype testing before July 14, 1989. The proposed rule would also permit the continued use of previously evaluated and approved sealed sources by NRC well logging licensees. The proposed rule is necessary because the current regulations unintentionally excluded the use of sealed sources previously approved by prototype testing.

TIMETABLE:

Proposed Action Published Undetermined

LEGAL AUTHORITY :

42 USC 2201; 42 USC 5841

EFFECTS ON SMALL BUSINESS AND OTHER ENTITIES: NO

AGENCY CONTACT:

Jean Trefethen

Office of Nuclear Regulatory Research

$301492-3867$ 
TITLE:

Uranium Tailings Regulations; Conforming

NRC Requirements to EPA Standards

RIN :

3150-AE77

CFR CITATION:

10 CFR 40

ABSTRACT :

The proposed rule would conform the Commission's regulations governing uranium mill tailings to the Environmental Protection Agency (EPA) standards promulgated under the Uranium Mill Tailings Radiation Control Act. In accordance with section 112(d)(9) of the clean Air Act Amendments of 1990, the EPA may rescind 40 CFR Part 61 , Subpart $T$ as it applies to NRC licensees subject to a finding that the NRC regulatory program protects the public health with an ample margin of safety. In october 1991, NRC, EPA, and the affected NRC Agreement states, executed a Memorandum of Understanding to address the actions to be undertaken by EPA and NRC to eliminate regulatory redundancy and to ensure that uranium mill tailings disposal sites are closed as expeditiously as practicable considering technical feasibility. The EPA has proposed amendments to the regulations pertaining to uranium mill tailings disposal sites in 40 CFR 192, subpart D, to ensure timely emplacement of a permanent radon barrier and to require monitoring for nonoperational uranium mill tailings disposal sites that are licensed by NRC or one of its Agreement states (June 8, 1993; 58 FR 32174). The NRC is required to conform its regulations governing uranium mill tailings to EPA's generally applicable standards promulgated under the Uranium Mill Tailings Radiation Control Act. NRC noted its intention to amend Appendix A of 10 CFR Part 40 to conform to EPA's planned amendments to 40 CFR 192, Subpart D, in an Advance Notice of Proposed Rulemaking entitled, "Licensing of Source Material" (October 28, 1992 ; 57 FR 48749).

\section{TIMETABLE :}

Proposed Action Published 11/00/93

Final Action Published 05/00/94

LEGAL AUTHORITY:

42 USC 2201; 42 USC 5841

EFFECTS ON SMALL BUSINESS AND OTHER ENTITIES: Undetermined 
TITLE :

Uranium Tailings Regulations; Conforming NRC Requirements to EPA Standards

AGENCY CONTACT:

Catherine R. Mattsen

Office of Nuclear Regulatory Research

$301492-3638$ 
TITLE :

Thermal Annealing of the Reactor Pressure Vessel

RIN :

$3150-\mathrm{AE} 45$

CFR CITATION:

10 CFR 50

ABSTRACT :

The proposed rule would amend the Commission's

regulations to define and clarify the requirements on

thermal annealing of reactor vessels to mitigating

neutron irradiation embrittlement. The proposed rule would reduce the potential for confusion stemming from addressing thermal annealing in two rules and would result in a clear and more definitive regulatory process.

The proposed rule would also address the following requirements for thermal annealing: (1) the procedural aspects of requesting permission to anneal the pressure vessel and to return to operation after the annealing process; and (2) the general analysis, testing, and inspection issues that would be considered by the Director, office of Nuclear Reactor Regulation, in reviewing licensing submittals requesting permission to anneal to return to operation.

TIMETABLE :

Proposed Action Published 01/00/94

Final Action Published 10/00/94

LEGAL AUTHORITY:

42 USC 2201; 42 USC 5841

EFFECTS ON SMALL BUSINESS AND OTHER ENTITIES: NO

AGENCY CONTACT:

Al Taboada

Office of Nuclear Regulatnry Research

301 492-3838 
TITLE:

Consideration of the Possible Effects of Power

Reactor Ownership Arrangements on Safety

RIN :

3150-AE48

CFR CITATION:

10 CFR 50

ABSTRACT:

The Commission is considering amending its regulations to increase assurance that NRC's power reactor licensees will have adequate funds for decommissioning and other safety-related activities. This rulemaking will consider the need for amending the NRC's regulations to require power reactor licensees to either: (1) guarantee any unfunded decommissioning liability with a surety bond letter of credit, or other guarantee method currently allowed in 10 CFR 50.75 (e)(1)(iii); (2) provide for a financial test guarantee mechanism similar to the one contained in 10 CFR Part 30, Appendix A; or (3) provide a certification to the NRC from the licensee's rate-making authority that it will allow unfunded decommissioning obligations to be collected in rates, notwithstanding the operating status of the facility.

TIMETABLE:

ANPRM Published Undetermined

LEGAL AUTHORITY:

42 USC 2201; 42 USC 5841

EFFECTS ON SMALL BUSINESS AND OTHER ENTITIES: NO

AGENCY CONTACT:

Robert Wood

Office of Nuclear Reactor Regulation

$301504-1255$ 
TITLE:

Safety Requirements for Reactor Coolant Pump Seals

RIN :

3150-AE53

CFR CITATION:

10 CFR 50

ABSTRACT :

The proposed rule would amend the Commission's regulations to require PWR plants to address the NRC's safety concerns regarding the ability of each plant to limit leakage from the pump seals during conditions such as station blackout and loss of component cooling water or service water. Seal failures experienced so far have had the benefit of available emergency core cooling systems. A LOCA from seal failures coupled with common cause failures that disable ECCS was found to be a significant contributor to public risk. This issue has been given a high priority for resolution through rulemaking.

In addition to development of a rule, the NRC staff intends to prepare a regulatory guide that will provide the methods acceptable for complying with the proposed RCP seal rule.

TIMETABLE:

Proposed Action Published 01/00/94

Final Action Published 01/00/95

LEGAL AUTHORITY:

42 USC 2201; 42 USC 5841

EFFECTS ON SMALL BUSINESS AND OTHER ENTITIES: NO

AGENCY CONTACT:

Syed K. Shaukat

Office of Nuclear Regulatory Research

$301 \quad 492-3934$ 
TITLE :

Changes to Quality Assurance Programs

RIN :

3150-AE70

CFR CITATION:

10 CFR 50

ABSTRACT :

The proposed rule would amend the Commission's

regulations to allow licensees to make changes to their quality assurance program that do not reduce the

program's content below that necessary to implement the quality assurance requirements prescribed in the regulations without prior NRC approval. The proposed rule would aiso require licensees to submit periodic reports of these changes to the NRC. The proposed rule is intended to reduce the regulatory burden on the NRC staff and the licensees.

TIMETABLE :

Proposed Action Published Undetermined

LEGAL AUTHORITY:

42 USC $2201 ; 42$ USC 5841

EFFECTS ON SMALL BUSINESS AND OTHER ENTITIES: NO

AGENCY CONTACT:

Claudia M. Craig

Office of Nuclear Reactor Regulation

$301504-1281$ 


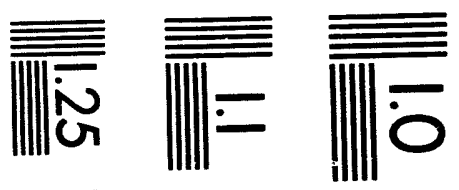

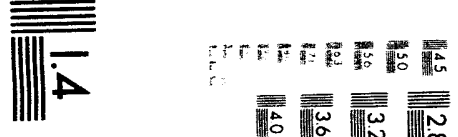

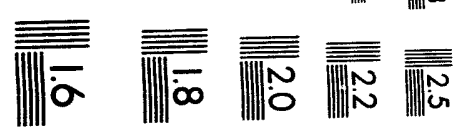



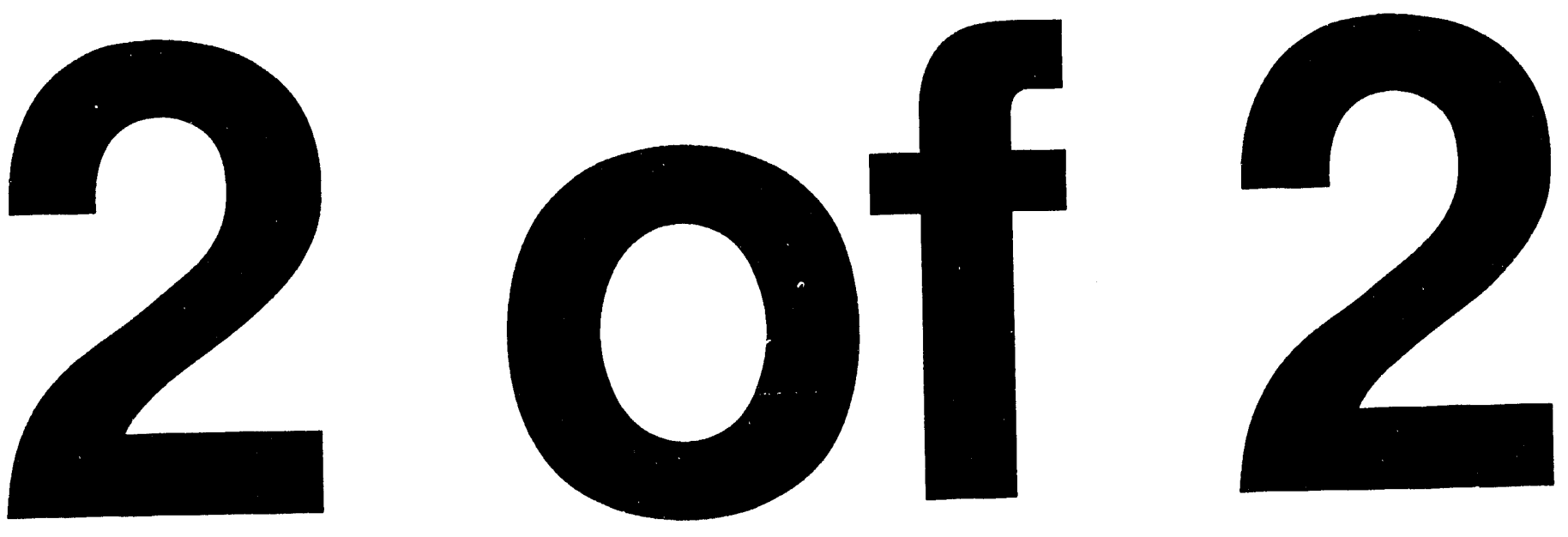
TITLE:

Definition of Commitment

RIN :

3150-AE74

CFR CITATION:

10 CFR 50

ABSTRACT :

The proposed rule would amend the commission's power reactor safety regulations to define the term commitment and to outline the change mechanism that would be used for a license who wishes to modify a commitment. This action is intended to reduce the regulatory burden on the NRC staff and the licensees.

\section{TIMETABLE :}

Proposed Action Published Undetermined

IEGAL AUTHORITY:

42 USC 2201; 42 USC 5841

EFFECTS ON SMALL BUSINESS AND OTHER ENTITIES: NO

AGENCY CONTACT:

Claudia M. Craig

office of Nuclear Reactor Regulation

301 504-1281 
TITLE :

Changes to Fire Protection Plans

RIN :

3150-AE73

CFR CITATION:

10 CFR 50

ABSTRACT :

The proposed rule would amend the Commission's power

reactor safety regulations to allow licensees to make changes to their fire protection plan that do not reduce the plans' content below that necessary to implement the fire protection requirements prescribed in the regulations without prior NRC approval. The proposed rule would also require licensees to submit periodic reports of these changes to the NRC. The proposed rule is intended to reduce the regulatory burden on the NRC staff and the licensees.

TIMETABLE:

Proposed Action Published Undetermined

LEGAL AUTHORITY:

42 USC 2201; 42 USC 5841

EFFECTS ON SMALL BUSINESS AND OTHER ENTITIES: NO

AGENCY CONTACT:

Claudia M. Craig

Office of Nuclear Reactor Regulation

$301504-1281$ 
TITLE:

Changes to Emergency Plans

RIN :

3150-AE72

CFR CITATION:

10 CFR 50

ABSTRACT:

The proposed rule would amend the Commission's power reactor safety regulations to allow licensees to make changes to their emergency plans that do not reduce the plans' content below that necessary to implement the emergency planning requirements prescribed in the regulations without prior NRC approval. The proposed rule would also require licensees to submit periodic reports of these changes to the NRC. The proposed rule is intended to reduce the regulatory burden on the NRC staff and the licensees.

TIMETABLE :

Proposed Action Published Undetermined

LEGAL AUTHORITY:

42 USC 2201; 42 USC 5841

EFFECTS ON SMALL BUSINESS AND OTHER ENTITIES: NO

AGEIICY CONTACT:

Claudia M. Craig

Office of Nuclear Reactor Regulation

$301 \quad 504-1281$ 
TITLE:

Changes to security Flans

RIN :

3150-AE71

CFR CITATION:

10 CFR 50

ABSTRACT :

The proposed rule would amend the commission's reactor safety regulations to allow licensees to make changes to their safeguards contingency plan, security plan, and guard training and qualification plan that do not reduce the plans' content below that necessary to

implement the applicable requirements prescribed in the regulations without prior NRC approval. The proposed rule would also require licensees to submit periodic reports of these changes to the NRC. The proposed rule is intended to reduce the regulatory burden on the NRC staff and the licensees.

TIMETABLE:

Proposed Action Published Undetermined

LEGAL AUTHORITY:

42 USC 2201; 42 USC 5841

EFFECTS ON SMALL BUSINESS AND OTHER ENTITIES: NO

AGENCY CONTACT :

Claudia M. Craig

Office of Nuclear Reactor Regulation

301 504-1281 
TITLE :

Codes and Standards for Nuclear Power Plants (ASME B\&PV Code, 1989/1990/1991/1992/1993 Addenda and 1992

Edition, Appendix VIII, Safety-Related Snubbers and the ASME OM Code-1990 Edition, 1992 Addenda and 1993

Addenda)

RIN :

3150-AE26

CFR CITATION:

10 CFR 50

ABSTRACT :

The proposed rule would amend the Commission's

regulations to incorporate by reference the 1989

Addenda, 1990 Addenda, 1991 Addenda, 1992 Addenda, 1993

Addenda, and 1992 Edition of Section III, Division 1, of the American Society of Mechanical Engineers Boiler and Pressure Vessel Code (ASME B\&PV Code); the 1989

Addenda, 1990 Addenda, 1991 Addenda, 1992 Addenda, 1993 Addenda, and 1992 Edition of Section XI, Division 1, of the ASME B\&PV Code. Additionally, the proposed amendment would expedite implementation of Appendix VIII of section XI, Division 1, which provides rules for performance demonstration of ultrasonic examination systems. The proposed amendment would expand the scope of $\$ 50.55 a$ to require inservice testing and examinations of safety-related snubbers. The proposed amendment would, for the first time, incorporate by reference the 1990 Edition, 1992 Addenda and 1993 Addenda of the ASME Code for operation and Maintenance of Nuclear Power Plants (ASME OM Code).

The ASME B\&PV Code provides rules in section III, Division 1, for the construction of components of light-water-cooled nuclear power plants. Section XI, Division 1, provides rules for the inservice inspection of those components. Requiring licensees to expedite implementation of Appendix VIII would improve the quality of inservice inspections in a timely manner. Expanding the scope of $\$ 50.55$ a to include safetyrelated snubbers would ensure that these components are tested to quality standards commensurate with the importance of the safety functions to be performed. The ASME OM Code provides rules for the inservice testing of pumps, valves, and snubbers. This proposed amendment would permit the use of improved methods for the construction, inservice inspection, and inservice testing of nuclear power plant components. Further, these actions would save applicants/licensees and the 
TITLE :

Codes and Standards for Nuclear Power Plants (ASME B\&PV Code, 1989/1990/1991/1992/1993 Addenda and 1992

Edition, Appendix VIII, Safety-Related Snubbers and the ASME OM Code-1990 Edition, 1992 Addenda and 1993

Addenda)

ABSTRACT: (cont)

NRC staff both time and effort by providing uniform detailed criteria against which the staff could review any single submission.

TIMETABLE:

Proposed Action Published 08/00/94

Final Action Published 06/00/95

LEGAL AUTHORITY:

42 USC 2201; 42 USC 5846

EFFECTS ON SMALL BUSINESS AND OTHER ENTITIES: NO

AGENCY CONTACT:

Wan Cheng (Winston) Liu

Office of Nuclear Regulatory Research

$301 \quad 492-3822$ 
TITLE:

Codes and Standards for Nuclear Power Plants (ASME Code, Section XI, Division 1, Subsection IWE and Subsection IWL)

RIN :

3150-AC93

CFR CITATION:

10 CFR 50

ABSTRACT:

The proposed rule would incorporate by reference subsection IWE, "Requirements for Class MC Components of Light-Water cooled Power Plants," and Subsection IWL, "Requirements for Class CC Concrete Components of Light-Water cooled Power Plants," of Section XI (Division 1) of the American Society of Mechanical Engineers Boiler and Pressure Vessel Code (ASME Code). Subsection IWE provides the rules and requirements for inservice inspection, repair, and replacement of class MC pressure retaining components and their integral attachments in light-water cooled power plants. Subsection IWL provides the rules and requirements for inservice inspection and repair of the reinforced concrete and post tensioning systems of Class CC components.

Incorporation by reference of subsection IWE and Subsection IWL will provide systematic examination rules for containment structure for meeting criterion 53 of the General Design Criteria (Appendix A of $10 \mathrm{CFR}$ Part 50) and Appendix $J$ of 10 CFR Part 50. Age-related degradation of containments has occurred, and additional and potentially more serious degradation mechanisms can be anticipated as nuclear power plants age.

If the NRC did not take action to endorse the Subsection IWE and subsection IWL rules, the NRC position on examination practices for containment structure would have to be established on a case-bycase basis and improved examination practices for steel containment structures might not be implemented. The other alternatives of incorporating these detailed examination requirements into the American National Standard ANSI/ANS 56.8-1981 or into Appendix J are not feasible. 
TITLE:

Codes and Standards for Nuclear Power Plants (ASME Code, Section XI, Division 1, Subsection IWE and Subsection IWL)

ABSTRACT: (CONT) Incorporating by reference the latest edition and addenda of subsection IWE and subsection IWL will save applicants/licensees and the NRC staff both time and effort by providing uniform detailed criteria against which the staff can review any single submission.

Adoption of the proposed amendment would permit the use of improved methods for containment inservice inspection.

TIMETABLE:

Proposed Action Published Undetermined

Final Action Published Undetermined

LEGAL AUTHORITY:

42 USC 2201; 42 USC 5841

EFFECTS ON SMALL BUSINESS AND OTHER ENTITIES: NO

AGENCY CONTACT:

Wallace E. Norris

Office of Nuclear Regulatory Research

$301 \quad 492-3805$ 
TITLE:

Fracture Toughness Requirements for LWR Pressure

Vessels

RIN :

3150-AD57

CFR CITATION:

10 CFR 50; Appendices $G$ and $H$

ABSTRACT:

The proposed rule would amend the Commission's regulations concerning fracture toughness requirements to resolve issues that have resulted from technological improvements and other factors. The "Pressurized Thermal shock (PTS) rule" (10 CFR 50.61), was modified in 1991 to be consistent with the embrittlement correlations given in Regulatory Guide 1.99, Revision 2. However, the need for further clarifications to the PTS rule has been identified. At a minimum, the proposed clarifications would --

(1) indicate that $\mathrm{RT}_{\mathrm{PTS}}$ values may be reduced using credible surveillance data;

(2) include reduced margin terms for cases in which credible surveillance data are used; and

(3) indicate that thermal annealing is an acceptable method for reducing $\mathrm{RT}_{\mathrm{PTS}}$ to values below the screening criteria, pursuant to the requirements of (proposed) 10 CFR 50.66 .

App sndix G to 10 CFR Part 50 provides fracture toughness requirements for feritic materials of pressure-retaining components of the reactor coolant boundary of light-water nuclear power reactors. The proposed changes, principally clarifications, in Appendix G to 10 CFR Part 50 would:

(1) explicitly indicate that pressure and leak tests of the RPV required by the ASME code must be completed before the core is critical (as agreed to by the CRGR on November 29, 1989);

(2) restructure sections IV and $V$ for clarification;

(3) change the reference from Appendix G of Section III of the ASME Code to Appendix $G$ of section XI of the ASME Code; and

(4) reword section V.D. to indicate that thermal annealing of the RRV should be conducted pursuant to (proposed) 10 CFR 50.66 . 
TITLE :

Fracture Toughness Requirements for LWR Pressure Vessels

ABSTRACT: (CONT)

Appendix $\mathrm{H}$ to $10 \mathrm{CF}$ Part 50 contains requirements for RPV material surveillance programs that are intended to monitor fracture toughness property changes in RPV materials due to irradiation embrittlement. The proposed changes in Appendix H to 10 CFR Part 50 would:

(1) address requirements for surveillance programs in the case of a license renewal request; and

(2) Clarify the earliest edition of ASTM E 185 (Standard Practice for Conducting Surveillance Tests for Light-Water cooled Nuclear Power Reactor Vessels) required for the surveillance program.

TIMETABLE:

Proposed Action Published 01/00/94

Final Action Published 10/00/94

LEGAL AUTHORITY:

42 USC 2201; 42 USC 5841

EFFECTS ON SMALL BUSINESS AND OTHER ENTITIES: NO

AGENCY CONTACT:

Allen L. Hiser, Jr.

Office of Nuclear Regulatory Research

$301 \quad 492-3988$ 
TITLE:

Standardized Plant Designs, Early Review of Site Suitability Issues; Clarifying Amendments

RIN :

3150-AE25

CFR CITATION:

10 CFR 50; 10 CFR 52; 10 CFR 140

ABSTRACT:

The proposed rule would amend the Commission's

regulations by deleting Appendices $M, N, O$, and $Q$ from 10 CFR Part 50. The NRC is also proposing to make clarifying changes to $10 \mathrm{CFR}$ Parts 52 and 140 to make clear that licensees are required to submit accurate and complete information to the NRC, and that its Price-Anderson requirements apply to combined license holders.

TIMETABLE:

Proposed Action Published Undetermined

LEGAL AUTHORITY:

42 USC 2201; 42 USC 5841

EFFECTS ON SMALL BUSINESS AND OTHER ENTITIES: Undetermined

AGENCY CONTACT:

Geary S. Mizuno

Office of the General counsel

$301504-1639$ 
TITLE:

*Design Certification for Evolutionary Light Water Reactors

RIN :

3150-AE8 7

CFR CITATION:

10 CFR 52

ABSTRACT:

The advance notice of proposed rulemaking (ANPRM) would request public comment on the Commission's regulations pertaining to the form and content of rules that would certify evolutionary designs of nuclear power plints. The NRC is reviewing two applications for standard design certifications for two evolutionary nuclear power plant designs pursuant to 10 CFR Part 52, subpart B. The NRC anticipates that these applications for design certification would be ready for the rulemaking phase of design certification in 1994 .

TIMETABLE:

ANPRM Published 11/00/93

Proposed Action Published

$09 / 00 / 94$

LEGAL AUTHORITY :

42 USC $2201 ; 42$ USC 5841

EFFECTS ON SMALI BUSINESS AND OTHER ENTITIES: NO

AGENCY CONTACT:

Harry Tovmassian/Jerry Wilson

Office of Nuclear Regulatory Research

Office of Nuclear Reactor Regulation

301 492-3634/301 504-3145 
TITLE:

Design Basis Events

RIN :

3150-AD51

CFR CITATION:

10 CFR 60

ABSTRACT :

The proposed rule would amend the Commission's

regulations concerning additional preclosure regulatory

requirements for high-level waste geologic

repositories. Several issues associated with

preclosure regulatory requirements have been raised due

to different interpretations of the rulemaking record

for 10 CFR Part 60. These involve: (1) the lack of

clearly prescribed requirements for the establishment

of a controlled-use area intended to protect public

health and safety in the event of a postulated

radionuclide release; and (2) the definition of

structures, systems, and components important to safety

for which certain design and quality assurance criteria

apply. In order to meet the milestones mandated by the Nuclear Waste Policy Act of 1982, as amended, and

milestones pertaining to DOE's production schedule in the Mission Plan amendments, guidance is needed from NRC on these matters to enable DOE to proceed with the siting of a geologic repository.

The proposed amendments would require the establishment of a controlled-use area, based on radiation dose

criteria, for the siting of geologic repositories. In addition, a new definition of structures, systems, and components important to safety would be added that would be similar to one in 10 CFR Part 72 .

\section{TIMETABLE :}

Proposed Action Published 03/00/94

Final Action Published 05/00/95

LEGAL AUTHORITY:

Public Law 97-425; 42 USC 10101

EFFECTS ON SMALL BUSINESS AND OTHER ENTITLES: NO

AGENCY CONTACT:

Janet P. Kotra

office of Nuclear Material Safety and Safeguards $301504-3620$ 
TITLE:

* Land Ownership Requirements for Low-Level Waste Sites

RIN :

3150-AE88

CFR CITATION:

10 CFR 61

ABSTRACT:

The advance notice of proposed rulemaking (ANPRM) would request public comment on allowing a licensee to own land that is used for a low-level waste disposal site. Current regulations require Federal or state ownership of land used for a low-level waste disposal site. The State of Utah (an agreement State) used an exemption provision to allow Envirocare (the licensee) to own the site.

TIMETABLE :

ANPRM Published 11/00/93

LEGAL AUTHORITY:

42 USC 2201; 42 USC 5841

EFFECTS ON SMALL BUSINESS AND OTHER ENTITIES: NO

AGENCY CONTACT:

Mark Haisfield/Ronald Uleck

Office of Nuclear Regulatory Research

office of Nuclear Material Safety and Safeguards

$301492-3877 / 301504-2595$ 


\section{TITLE:}

Financial Assurance for Low-Level Waste Disposal Site Surveillance, Monitoring, and Custodial Care

RIN :

3150-AE76

CFR CITATION:

IO CFR 61

ABSTRACT' :

The proposed rule would amend the Commission's regulations by adding requirements for financial assurance for the 100-year institutional control period, during which time surveillance, monitoring and custodial care, would be carried out at low-level radioactive waste disposal sites. The proposed rule would implement Section 151 of the Nuclear Waste Policy Act of 1982, which gives the NRC the authority to establish these requirements.

TIMETABLE :

Proposed Action Published 06/00/94

Final Action Published 06/00/95

LEGAL AUTHORITY:

42 USC 2201; 42 USC 5841

EFFECTS ON SMALL BUSINESS AND OTHER ENTITIES: NO

AGENCY CONTACT:

Clark Prichard

Office of Nuclear Regulatory Research

301 492-3734 
TITLE:

Removal of Criticality Alarm Requirements for Fresh Fuel

RIN :

3150-AE4 3

CFR CITATION:

10 CFR 70

ABSTRACT :

The proposed rule would amend the Commission's regulations to eliminate the need for licensees to request an exemption from provisions that require criticality monitors for new reactor fuel. An exemption for this requirement is routinely granted when requested by a licensee. The proposed rule would allow reactor licensees to dispense with unneeded criticality monitors without having to request an exemption.

\section{TIMETABLE :}

Proposed Action Published 01/00/94

Final Action Published 11/00/94

LEGAL AUTHORITY:

42 USC 2201; 42 USC 5841

EFFECTS ON SMALL BUSINESS AND OTHER ENTITIES: NO

AGENCY CONTACT:

Jerry E. Jackson

Office of Nuclear Regulatory Research

301 492-3923 
TITLE :

Physical Fitness programs for Security Personnel at Category I Licensee Fuel Cycle Facilities

RIN :

$$
3150-\mathrm{AD} 30
$$

CFR CITATION:

10 CFR 73

ABSTRACT:

The proposed rule would amend the Commission's regulations to include a standardized physical fitness training program and fitness standards for security personnel.

Current regulations specify that security personnel have no physical weaknesses that would adversely affect their performance of assigned job duties. However, regulatory standards ensuring that security personnel are physically fit to perform their duties do not exist. Requirements for a physical fitness program and fitness standards at Category I fuel cycle facilities for security personnel need to be added to the regulations in order to provide a uniform, enforceable program. Guidance will be developed to ensure that such a program will not, at the same time, endanger the health of those participating in it.

TIMETABLE: Proposed Action Published 10/06/93

Final Action Published 08/00/94

LEGAL AUTHORITY:

42 USC 2201; 42 USC 5841

EFFECTS ON SMALI, BUSINESS AND OTHER ENTITIES: No

AGENCY CONTACT:

Harry S. Tovmassian

Office of Nuclear Regulatory Research

$301492-3634$ 
TITLE:

Reinvestigation of Individuals Granted Unescorted

Access to Nuclear Power Plants

RIN :

$3150-A D 49$

CFR CITATION:

10 CFR 73

ABSTRACT :

The final rule would amend the Commission's regulations to require periodic updates of FBI fingerprint checks for reinvestigation of individuals granted unescorted access to nuclear power plants or access to safeguards information. The proposed rule would require that licensees who operate a nuclear power plant submit fingerprint cards for applicable personnel to the NRC for criminal history checks every 5 years.

Authorization for unescorted access would be retained

by an individual pending results of the criminal

history check on that individual.'s fingerprints.

TIMETABLE :

Final Action Undetermined

LEGAL AUTHORITY:

42 USC $2201 ; 42$ USC 5841

EFFECTS ON SMALL BUSINESS AND OTHER ENTITIES: No

AGENCY CONTACT:

Sandra Frattali

Office of Nuclear Regulatory Research

$301492-3773$ 


\section{TITLE:}

Night Firing Qualifications for security Guards at Nuclear Power Plants

RIN :

$$
3150-A C 88
$$

CFR CITATION:

$$
10 \text { CFR } 73
$$

\section{ABSTRACT :}

The proposed rule would amend the Commission's regulations to ensure that security force effectiveness at nuclear power plants is not dependent on the time of day. Security guards currently are required to perform night firing for familiarization only. There is no requirement for standards to measure their effectiveness. The proposed rule would require that security guards at nuclear power plants qualify for night firing.

Part 73, Appendix B, Part IV, would be amended to require reactor security guards to qualify annually in an NRC-approved night firing course with their assigned weapons. The proposed amendment would standardize training and qualification in night firing and prepare power reactor guard forces to respond more effectively in the event of an incident occurring in limited lighting conditions.

TIMETABLE :

Proposed Action Published Undetermined

LEGAL AUTHORITY :

42 USC 2201; 42 USC 5841

EFFECTS ON SMALL BUSINESS AND OTHER ENTITIES: NO

AGENCY CONTACT:

John Telford

Office of Nuclear Regulatory Research

$301492-3796$ 
TITLE:

Physical Protection of Special Nuclear Material in Transit

RIN :

3150-AEO2

CFR CITATION:

10 CFR 73

ABSTRACT:

The proposed rule would amend the commission's regulations for the transport of category I materials to provide a level of protection for these materials while in transit comparable to that provided by the U.S. Department of Energy (DOE). This amendment would reduce reliance on DOE's Safe Secure Trailer program for secure shipments of Category I material.

TIMETABLE:

Proposed Action Published Undetermined

LEGAL AUTHORITY:

42 USC 2201; 42 USC 5841

EFFECTS ON SMALL BUSINESS AND OTHER ENTITIES: NO

AGENCY CONTACT:

Priscilla A. Dwyer

Office of Nuclear Material Safety and Safeguards

301 504-2478 
TITLE :

*Protection Against Malevolent Use of Vehicles at Nuclear Power Plants

RIN :

$$
\text { 3150-AE81 }
$$

CFR CITATION:

10 CFR 73

\section{ABSTRACT:}

The proposed rule would amend the Commission's physical protection regulations for operating nuclear power reactors. The proposed amendment would modify the design basis threat for radiological sabotage to include use of a land vehicle by adversaries for transporting personnel, hand-carried equipment and/or explosives. The commission believes this action is prudent based on the evaluation of an intrusion incident at the Three Mile Island nuclear power station and the bombing at the World Trade Center. The objective of the rule is to enhance reactor safety by precluding the malevolent use of a vehicle to gain unauthorized proximity to a vital area barrier. Further, the rule would enhance reactor safety by protecting vital equipment from damage by detonation of an explosive charge at the point of vehicle denial.

TIMETABLE :

Proposed Action Published 11/00/93

Final Action Published 02/00/94

LEGAL AUTHORITY:

42 USC $2201 ; 42$ USC 5841

EFFECTS ON SMALL BUSINESS AND OTHER ENTITIES: NO

AGENCY CONTACT:

Phillip F. McKee/Priscilla A. Dwyer

office of Nuclear Reactor Regulation

office of Nuclear Material Safety and Safeguards $301504-2933 / 301504-2478$ 
TITLE:

Standards for Certification of DOE Uranium Enrichment Gaseous Diffusion Facilities

RIN :

3150-AE62

CFR CITATION:

10 CFR 76

ABSTRACT:

The proposed rule would amend the commission's

regulations by adding a new part to the code of Federal Regulations (10 CFR Part 76). The Energy Policy Act of 1992 (the Act) authorized the establishment of a new government corporation, U.S. Enrichment Corporation (USEC), for the purpose of conducting a uranium enrichment enterprise. The Act directs the NRC to issue standards by rulemaking as necessary to govern the gaseous diffusion plants at Portsmouth, Ohio, and Paducah, Kentucky, in order to protect the public health and safety from radiological hazard, and provide for the common defense and security, including adequate safeguards. The standards are to be in effect within 2 years. This new part will include as certification standards pertinent parts of existing regulations as they are applied to similar facilities licensed by the NRC.

TIMETABLE:

Proposed Action Published 11/00/93

Final Action Published 10/00/94

LEGAL AUTHORITY:

42 USC $2201 ; 42$ USC 5841

EFFECTS ON SMALL BUSINESS AND OTHER ENTITIES: NO

AGENCY CONTACT:

Charles $W$. Nilsen

Office of Nuclear Regulatory Research

$301 \quad 492-3834$ 
(A) Petitions incorporated into final rules or petitions denied since June 30, 1993 
PETITION DOCKET NO:

PRM-35-8

PETITIONER:

Amersham Corporation

PART:

35

OTHER AFFECTED PARTS:

None

FEDERAL REGISTER CITATION:

May 5, 1989 (54 FR 19378)

SUBJECT:

Iridium-192 Wire for the Interstitial Treatment of Cancer

SUMMARY :

The petitioner requested that the Nuclear Regulatory

commission amend its regulations concerning the medical use of byproduct material to include Iridium-192 wire for interstitial treatment of cancer in the provisions of $10 \mathrm{CFR} 35.400$ which governs the use of sources for brachytherapy.

\section{TIMETABLE:}

The petitioner withdrew this petition for rulemaking in March 1993. A notice announcing the withdrawal of this petition was published in the Federal Register on August 23, 1993 (58 FR 44466).

CONTACT:

Anthony Tse

Office of Nuclear Regulatory Research

$301 \quad 492-3797$ 
(B) Petitions incorporated into proposed rules NONE 


$$
\begin{aligned}
& 0 \\
& 0 \\
& 0 \\
& 0 \\
& 0 \\
& 0 \\
& 0 \\
& 0 \\
& 0 \\
& 5 \\
& 0 \\
& 0 \\
& 0 \\
& 0 \\
& 0 \\
& 5 . \\
& 5 \\
& 0 \\
& 0 \\
& 0 \\
& 0 \\
& 0 \\
& 0 \\
& 0 \\
& 0 \\
& 0 \\
& 4 \\
& 5 . \\
& 0 \\
& 0
\end{aligned}
$$


PETITION DOCKET NUMBER:

PRM-2 0-20

PETITIONER:

Carol S. Marcus, Ph.D., M.D.

PART :

20

OTHER AFFECTED PARTS:

35

FEDERAL REGISTER CITATION:

June 12, 1991 (56 FR 26945)

SUBJECT:

Radiation absorbed dose to individuals from patients receiving radiopharmaceuticals for diagnosis or therapy

SUMMARY :

The petitioner requests that the Commission specify that the annual radiation dose absorbed by individuals exposed to patients administered radioactive materials be $5 \mathrm{mSv}$ ( 500 mrems).

TIMETABLE :

A notice of receipt for this petition was published in the Federal Register on June 12, 1991 (56 FR 26945). The comment period closed on October 12, 1991. Resolution of the petition is scheduled for rulemaking ("Dose Limits for Patients and Members of the Public" (RIN 3150-AE41)). A publication date for the proposed rule is scheduled for December 1993.

CONTACT:

Stewart Schneider

Nuclear Regulatory Commission

Office of Nuclear Regulatory Research

$301 \quad 492-3588$ 


\section{PETITION DOCKET NUMBER: \\ *PRM-20-21}

PETITIONER:

Keith J. Schiager, Ph.D., et al.

PART :

20

OTHER AFFECTED PARTS:

none

FEDERAL REGISTER CITATION:

September 10, 1993 (58 FR 47676)

SUBJECT :

Disposal of certain low-level radioactive wastes to provide additonal options for disposal of very low concentrations of short-lived radionuclides.

\section{SUMMARY:}

The petitioners request that the Nuclear Regulatory Commission (NRC) amend its regulations in 10 CFR Part 20 that will become mandatory for all licensees on January 1, 1994, to permit additional methods for disposal of certain low-level radioactive wastes. The petitioners contend that the regulations that become mandatory for all licensees on January 1, 1994, are too restrictive and prevent many research institutions from pursuing certain types of research that cannot be conducted effectively without the use of radioactive materials.

\section{TIMETABLE:}

A notice of receipt for this petition was published in the Federal Register on September 10, 1993 (58 FR 47676). The comment period closes on November 24, 1993. Resolution of this petition is scheduled for September 1994.

CONTACT :

George Powers

Office of Nuclear Regulatory Research

$301 \quad 492-3747$ 
PETITION DOCKET NO:

PRM-32-3

PETITIONER:

Advanced Medical Systems, Inc.

PART:

32

OTHER AFFECTED PARTS:

None

FEDERAL REGISTER CITATION:

October 10, 1991 (56 FR 51182)

SUBJECT :

Manufacture or transfer of certain items containing byproduct material

SUMMARY :

The petitioner requests that the Nuclear Regulatory Commission amend its regulations that apply to the manufacturers or transferors of certain items containing byproduct material to specify that these provisions apply to the manufacturers and distributors of replacement parts or original units.

\section{TIMETABLE:}

A notice of receipt for this petition was published in the Federal Register on October 10, 1991 (56 FR 51182). The comment period closed on December 9, 1991. Resolution of this petition is scheduled for December 1993.

CONTACT:

Naiem Tanious

Office of Nuclear Regulatory Research $301492-3878$ 
PETITION DOCKET NO:

PRM-34-4

PETITIONER:

International Union of Operating Engineers, Local No. 2

PART :

34

OTHER AFFECTED PARTS:

None

FEDERAL REGISTER CITATION:

December 4, 1992 (57 FR 57392)

SUBJECT :

Require a minimum of two radiographic personnel when performing industrial radiography with licensed materials at temporary job sites

SUMMARY :

The petitioner requests that the Nuclear Regulatory commission amend its regulations regarding licenses for radiography and radiation safety requirements for radiographic operations, as necessary, to require a minimum of two radiographic personnel when performing industrial radiography with licensed materials at temporary job sites. The petitioner believes that the suggested change is necessary to ensure a safe working environment.

\section{TIMETABLE:}

A notice of receipt for this petition was published in the Federal Register on December 4, 1992 (57 FR 57392). The public comment period closed on February 2, 1993. A proposed rule (Radiography and Radiation safety Requirements for Radiography operations - RIN 3150AE07) is being developed to address this petition. The proposed rule is scheduled for publication in December 1993.

CONTACT:

Don Nellis

Office of Nuclear Regulatory Research

$301492-3628$ 
PETITION DOCKET NUMBER:

PRM-35-10/PRM-35-10A

PETITIONER:

American College of Nuclear Medicine

PART :

35

OTHER AFFECTED PARTS:

None

FEDERAL REGISTER CITATION :

March 9, 1992 (57 FR 8282)

SUBJECT:

Radiopharmaceutical therapy

SUMMARY :

The petitioner requests that the Commission amend its regulations by deleting the requirement for mandated hospitalization for ambulatory patients receiving oral or IV radiopharmaceuticals in amounts greater than 30 millicuries and allowing patients the option to be treated on an outpatient basis if they qualify medically. The petitioner states that the requested amendment is in the best interest of patients who require access to affordable quality care and that published scientific data support the requested changes. The petitioner submitted an arnendment to this petition that was assigned Docket No. PRM-35-10A. The petitioner requests that the original petition be expanded to consider the need to allow amounts greater than 30 millicuries to be used in diagnostic studies and to add a definition of confinement.

TIMETABLE:

A notice of receipt for this petition was published in the Federal Register on March 9, 1992 (57 FR 8282). The comment period closed on May 8, 1992. A notice of receipt for $P R M-35-10 A$ was published in the Federal Register on May 18, 1992 (57 FR 21043). The comment period closed on July 17, 1992. Resolution of the petitions is scheduled for rulemaking ("Dose Limits for Patients and Members of the Public" (RIN 3150-AE41)). A publication date for the proposed rule is scheduled for December 1993.

CONTACT :

Stewart Schneider

Office of Nuclear Regulatory Research

$301492-3588$ 
PETITION DOCKET NUMBER:

PRM-50-53

PETITIONER :

The Ohio Citizens for Responsible Energy

PART :

50

OTHER AFFECTED PARTS: None

FEDERAL REGISTER CITATION: July 25, 1989 (54 FR 30905)

SUBJECT :

Request for Reopening of ATWS Rulemaking Proceeding

SUMMARY :

The petitioner requests that the NRC reopen the Anticipated Transients Without Scram (ATWS) rulemaking proceeding. This request was one portion of a request by the ohio citizens for Responsible Energy (OCRE) that NRC take a number of actions to relieve alleged undue risks posed by the thermal-hydraulic instability of boiling water reactors. On April 27, 1989, the Director, NRR, responded to the OCRE request for action in a Director's Decision under 10 CFR 2.206. In the Director's Decision (DD-89-03), the NRC denied all of the petitioner's requests, except for the request to reopen the ATWS rulemaking proceeding, which would be more properly treated as a petition for rulemaking under $10 \mathrm{CFR} 2.802$. The petitioner suggested that resolution of the ATWS problem depends on measures other than tripping the recirculation pumps to rapidly reduce reactivity. In this regard, the petitioner specifically suggests the use of an automatic, higi capacity standby liquid control system.

In a letter from the BWR Owner's Group (BWROG), dated September 18, 1989, which transmitted report NEDO31709, "Average Core Power During Large Core Thermal Hydraulic Oscillations in a BWR" the BWROG concluded that previous ATWS evaluations are valid and that existing ATWS provisions and actions are appropriate. The staff review of NEDO-31709 concluded that the NEDO analyses, and other analyses performed by the BWROG contractors, were not sufficient to support their conclusions.

NRC Staff and contractors studies of ATWS scenarios were performed to determine if the potential power oscillations could be significant enough to warrant an 
PETITION DOCKET NUMBER:

PRM $-50-53$

SUMMARY: (CONT)

ATWS rule change, modification of operator actions, or possible equipment/systems changes. Several of the ATWS scenarios revealed the need for more detailed studies of the automatic responses and emergency procedures guidelines (EPGs) used by plant operators.

The staff requested that the BWROG address the questions raised by the staff relative to operator actions and instrumentation adequacy for an ATWS with oscillations and the timing of the boron injection and water level reduction as effective means to control such transients. The BWROG studies were submitted to the staff in February 1992 (NEDO-32047). The staff has reviewed the BWROG analysis and has prepared a report to the commission outlining results of that review and the staff's proposed plans for resolution of this issue (SECY-92-386, November 16, 1992).

The BWROG has recently held progress meetings with the staff at which it presented its supplemental studies in progress. The BWROG will document these studies in a supplement to NEDO-32047. Also, the BWROG will submit a report on studies of the most appropriate mitigation actions and recommended changes to the Emergency Procedure Guidelines.

The NRC staff has nearly completed its review of the studies discussed at the progress meetings. However, as a result of considerations voiced during the NRC staff and industry presentations at the May 12, 1993, ACRS Joint Subcommittee meeting on Thermal-Hydraulic Phenomena and Core Performance, it was concluded that the stability issues (whose resolution is vital to enable a defendable response to the ATWS rulemaking petition) cannot be resolved independent of the industries' efforts to improve emergency operating procedures (EOP). The EOP improvement issue and the ATWS petition will be discussed at a meeting between the NRR staff and the BWR Owner's group, currently being planned for late october 1993. It is not presently known whether or not the remaining outstanding issues will be resolved at this meeting.

TIMETABLE:

Resolution of the petition can be expected within one month of resolution of outstanding issues between the NRC staff and the BWROG. 
PETITION DOCKET NUMBER:

PRM-50-53

CONTACT:

Roy Woods

Office of Nuclear Regulatory Research

301 492-3908 
PETITION DOCKET NUMBER:

PRM $-50-57$

PETITIONER:

North Carolina Public Utility Commission

PART :

50

OTHER AFFECTED PARTS:

140

FEDERAL REGISTER CITATION:

January 17, 1992; 57 FR 2059

SUBJECT :

Reduce or Eliminate Insurance for Nuclear Power Plants Awaiting Decommissioning

SUMMARY :

The petitioner requests that the Commission amend its regulations to substantially reduce or eliminate insurance requirements for nuclear power reactors when all the nuclear reactors on a reactor station site have been shut down and are awaiting decommissioning and all the nuclear fuel has been removed from the reactor site.

TIMETABLE:

A notice of receipt for this petition was published in the Federal Register on January 17, 1992 (57 FR 2059). The public comment period closed on March 17, 1992. Resolution of the petition is scheduled for December 1995.

CONTACT:

Carl Feldman

Office of Nuclear Regulatory Research

301 492-3883 
PETITION DOCKET NUMBER:

PRM-50-58

PETITIONER:

Virginia Electric and Power Company

PART :

50

OTHER AFFECTED PARTS:

None

FEDERAL REGISTER CITATION:

March 4, 1993; 58 FR 12339

SUBJECT :

Change the frequency of required emergency planning

exercises to biennially instead of annually.

SUMMARY :

The petitioner requests that the Commission amend its regulations to change the frequency of required emergency planning exercises to biennially instead of annually. The proposed amendment would require each 1 icensee to conduct, at each site, an integrated exercise every 2 years and to ensure that their emergency response capabilities are maintained duxing the 2-year interval.

TIMETABLE :

A notice of receipt for this petition was published in the Federal Register on March 4, 1993 (58 FR 12339). The public comment period ended on May 3, 1993. Resolution of the petition is scheduled for March 1994.

CONTACT:

Michael Jamgochian

Office of Nuclear Regulatory Research

$301492-3918$ 
PETITION DOCKET NUMBER:

PRM-60-3

PETITIONER:

Department of Energy

PART:

60

OTHER AFFECTED PARTS:

None

FEDERAL REGISTER CITATION:

July 13，1990 (55 FR 28771)

August 10, 1990 (55 FR 32639)

SUBJECT :

Disposal of High-Level Radioactive Waste

SUMMARY :

The petitioner requests that the commission amend its regulations pertaining to the disposal of high-level radioactive wastes in geologic repositories to include a specific dose criterion for design basis accidents. The petitioner believes this would facilitate the development and licensing of a geologic repository for high-level radioactive waste.

\section{TIMETABLE :}

This petition will be resolved with publication of the related rulemaking, "Design Basis Events" (RIN 3150AD51). The publication date for this proposed rule is scheduled for March 1994.

CONTACT :

Janet $P$. Kotra

office of Nuclear Material Safety and Safeguards $301504-3620$ 
PETITION DOCKET NUMBER:

PRM-61-2

PETITIONER:

New England Coalition on Nuclear Pollution, Inc.

PART :

61

OTHER AFFECTED PARTS:

None

FEDERAL REGISTER CITATION:

July 23, 1992 (57 FR 32743)

SUBJECT :

Waste classification of low-level radioactive waste

SUMMARY :

The petitioner requests that the commission amend its regulations regarding waste classification of low-level radioactive waste to restrict the number and types of waste streams that can be disposed of in near-surface disposal facilities. The petitioner also requests that the NRC prepare a supplemental environmental impact statement (EIS) to the original EIS prepared for 10 CFR Part 61 (December 27, 1982; 47 FR 57446).

TIMETABLE:

A notice of receipt for this petition was published in the Federal Register on July 23, 1992 (57 FR 32743).

The public comment period closed on september 21, 1992. Resolution of the petition is scheduled for November 1993.

CONTACT :

Mark Haisfield

office of Nuclear Regulatory Research

$301 \quad 492-3877$ 
PETITION DOCKET NUMBER:

*PRM-72-1

PETITIONER:

Maryland Safe Energy Coalition

PART:

72

OTHER AFFECTED PARTS:

None

FEDERAL REGISTER CITATION:

September 8, 1993 (58 FR 47222)

SUBJECT :

Dry cask storage

SUMMARY :

The petitioner requests that the commission amend its regulations regarding generic issues related to dry cask storage.

TIMETABLE:

A notice of receipt for this petition was published in the Federal Register on September 8, 1993 (58 FR

47222). The public comment period closes on November 22 , 1993. Resolution of the petition is scheduled for September 1994 .

CONTACT:

Gordon Gunderson

Office of Nuclear Regulatory Research

$301492-3803$ 
PETITION DOCKET NUMBER:

PRM-150-2

PETITIONER:

Envirocare of Utah, Inc.

PART:

150

OTHER AFFECTED PARTS: None

FEDERAL REGISTER CITATION:

February 22, 1993 (58 FR 5992)

SUBJECT :

Persons who generate or dispose of very low specific activity wastes contaminated with special nuclear materials

SUMMARY :

The petitioner requests that the commission amend its regulations to exempt those persons that generate or dispose of very low specific activity wastes contaminated with special nuclear materials that are not capable of forming a critical reaction from the current possession limits specified in its regulations.

TIMETABLE:

A notice of receipt for this petition was published in the Federal Register on February 22, 1993 (58 FR 9552). The public comment period closed on April 23, 1993. Resolution of the petition is scheduled for February 1994 .

CONTACT:

Carl Feldman

office of Nuclear Regulatory Research

$301492-3883$ 
PETITION DOCKET NUMBER:

PRM-170-3

PETITIONER:

American College of Nuclear Physicians and Society of Nuclear Medicine

PART :

170

OTHER AFFECTED PARTS:

171

FEDERAL REGISTER CITATION:

May 12, 1992 (57 FR 20211)

SUBJECT :

Fees for facilities, materials licenses, and other

regulatory service under the Atomic Energy Act of 1954, as amended.

SUMMARY :

The petitioner requests that the commission amend its regulations to mitigate the substantial adverse impacts experienced by its members because of the recent

increase in NRC's license and annual fees.

TIMETABLE :

A notice of receipt for this petition was published in the Federal Register on May 12, 1992 (57 FR 20211). A request for public comment on the petition was published in the Federal Register on October 13, 1992 (57 FR 46818). The comment period closed on Decem? $2 r$ 14 , 1992. Resolution of the petition is scheduled for June 1994 .

CONTACT :

C. James Holloway, Jr.

office of the controller

$301492-3201$ 
PETITION DOCKET NUMBER:

PRM-170-4

PETITIONER:

American Mining Congress

PART :

170

OTHER AFFECTED PARTS:

171

FEDERAL REGISTER CITATION:

April 19, 1993 (57 FR 21116)

SUBJECT :

Evaluation of fee policy

SUMMARY :

The petitioner requests that the commission amend its regulations to alleviate the inequitable impacts of NRC-imposed fees on its members, specifically for class I uranium recovery sites that have ceased operation and await NRC-approval of reclamation plans. The petitioner also suggests that the NRC implement certain standards for services provided. An advance notice of proposed rulemaking (NRC Fee Policy; Request for Public comment) was published in the Federal Register on April 19, 1993 (58 FR 21116) announcing the receipt of this petition for rulemaking.

TIMETABLE:

A notice of receipt for this petition was published in the Federal Register on April 19, 1993 (58 FR 21116). The comment period closed on August 18, 1993 (58 FR $39174)$. Resolution of the petition is scheduled for June 1994 .

CONTACT:

C. James Holloway, Jr.

office of the controller 301 492-4301 
(D) Petitions with deferred action NONE 

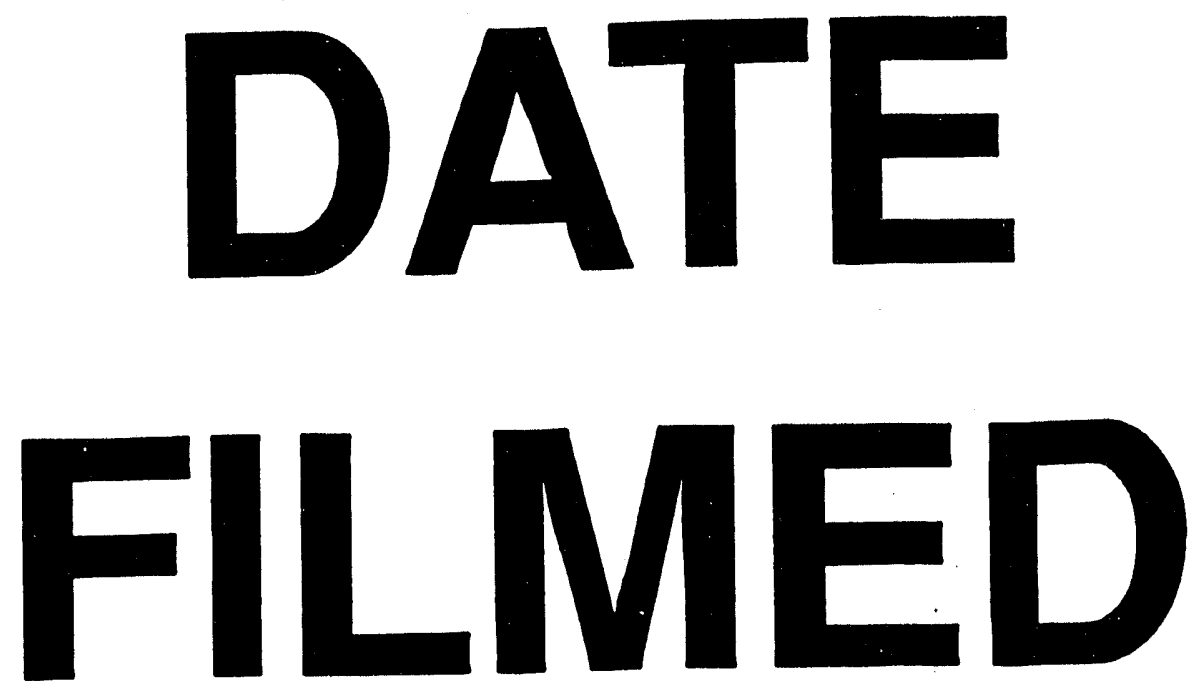

$12 / 22 / 93$
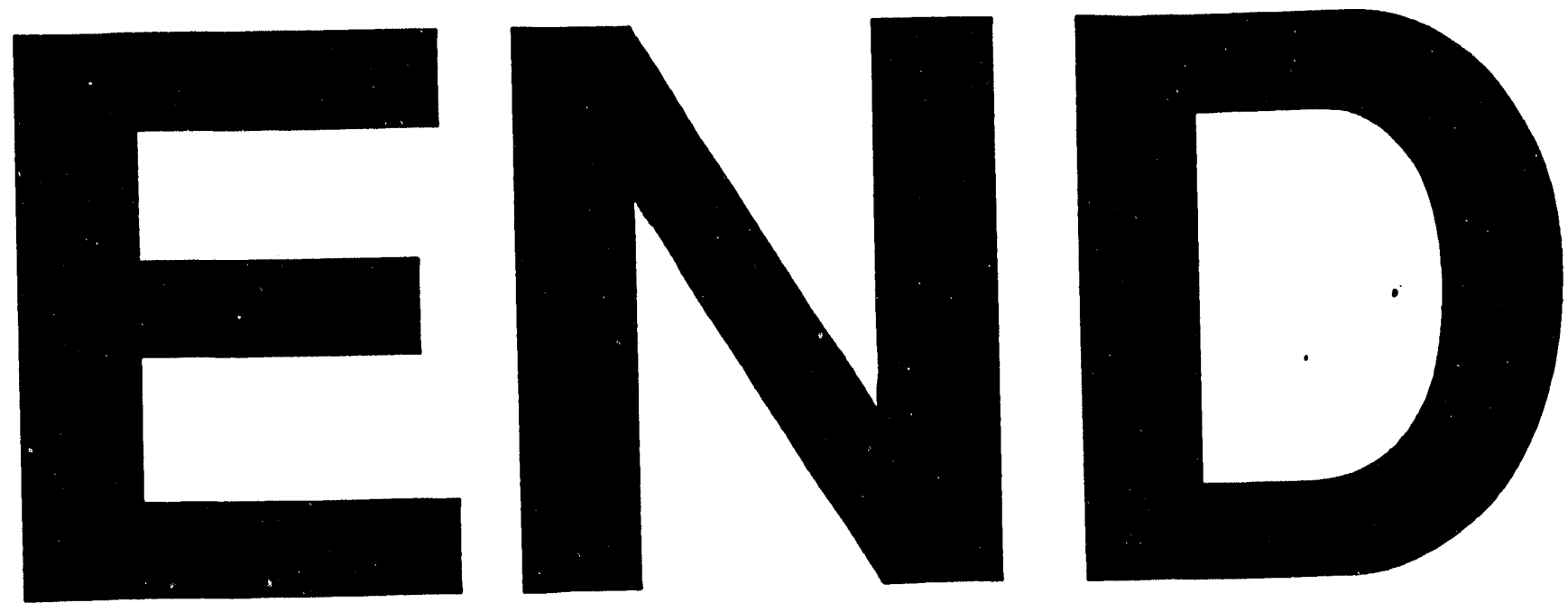


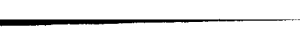

